\title{
A RESPONSABILIDADE OBJETIVA DO EMPREGADOR À LUZ DA PROTEÇÃO CONSTITUCIONAL CONFERIDA AO MEIO AMBIENTE DO TRABALHO
}

\author{
Pastora do Socorro Teixeira Leal ${ }^{1}$ \\ Universidade Federal do Pará (UFPA) Instituto de Ciências Jurídicas (ICJ) \\ Igor de Oliveira Zwicker ${ }^{2}$ \\ Universidade Federal do Pará (UFPA)
}

\section{RESUMO}

A importância dos direitos sociais é inquestionável, seja na razão de existir da República Federativa do Brasil, fundada na cidadania, dignidade humana e nos valores sociais do trabalho e da livre iniciativa; seja em seus objetivos fundamentais, de construir uma sociedade livre, justa e solidária, erradicar a pobreza e a marginalização, reduzir as desigualdades sociais e regionais e promover o bem de todos; seja em reconhecer, em nível global, a prevalência dos direitos humanos e o dever de cooperação entre os povos para o progresso da humanidade. A tutela labor-ambiental, lida a partir do macroprincípio da dignidade da pessoa humana, deve garantir a responsabilidade do empregador quanto às afetações ocorridas no meio ambiente do trabalho, em todos os seus matizes. Nesse sentido, propõe-se uma leitura constitucional adequada para se reconhecer, a partir da autonomia científica do Direito Ambiental do Trabalho, um microssistema de responsabilidade civil objetiva apto a responsabilizar o empregador-poluidor quando se verificar a prática de poluição labor-ambiental. No que diz

1 Pós-Doutora pela Universidad Carlos III de Madrid (UC3M). Doutora em Direito pela Pontifícia Universidade Católica de São Paulo (PUC-SP). Mestra em Direito pela Universidade Federal do Pará (UFPA). Bacharela em Direito pela UFPA. Professora de graduação e de pós-graduação (Mestrado e Doutorado) da UFPA e da Universidade da Amazônia (UNAMA). Desembargadora do Trabalho do Tribunal Regional do Trabalho (TRT) da $8^{a}$ Região (PA/AP). ORCID: https://orcid.org/0000-00015265-483X / e-mail: pastoraleal@uol.com.br

2 Doutorando em Direito pela Universidade Federal do Pará (UFPA). Mestre em Direitos Fundamentais pela Universidade da Amazônia (UNAMA). Especialista em Economia do Trabalho e Sindicalismo pela Universidade Estadual de Campinas (Unicamp), em Direito do Trabalho e Processo do Trabalho pela Universidade Candido Mendes (UCAM) e em Gestão de Serviços Públicos pela UNAMA. Bacharel em Direito pela UNAMA. Professor de Direito. Analista Judiciário (Área Judiciária) e Assessor Jurídico-Administrativo do Tribunal Regional do Trabalho (TRT) da $8^{\text {a }}$ Região (PA/AP). ORCID: https://orcid.org/0000-0001-7554-5126 / e-mail: igor.zwicker@uol.com.br 
respeito à metodologia, adotou-se linha crítico-metodológica e jurídico-propositiva, do olhar hermenêutico a uma análise crítica capaz de orientar o microssistema proposto. Conclui-se, ao final, pela necessidade prática de sua aplicação, como forma de resguardar e promover a dignidade da pessoa humana.

Palavras-chave: Direito Ambiental do Trabalho; efetividade; poluição labor-ambiental; responsabilidade civil objetiva; tutela labor-ambiental.

\section{EMPLOYER'S OBJECTIVE RESPONSIBILITY IN LIGHT OF CONSTITUTIONAL PROTECTION CONFERRED TO LABOR ENVIRONMENT}

\section{ABSTRACT}

The importance of social rights is unquestionable: in the very reason for existing of the Federative Republic of Brazil, founded on citizenship, human dignity, social values of work and free initiative; in its fundamental objectives to construct a free, fair and supportive society, to eradicate poverty and marginalization, to reduce social and regional inequalities and to promote the good to all; in recognize, at the global level, the prevalence of human rights and duty of cooperation among peoples for humanity's advancement. Labor-environmental protection, read from the macroprinciple of dignity of the human person, must find ways to guarantee the responsibility of the employer regarding affectations occurred in labor environment, in all nuances. In this sense, it is proposed an adequate constitutional reading to recognize, from the scientific autonomy of Environmental Labor Law, a microsystem of objective civil responsibility able to charge employer-polluter when he's polluted the labor environment. The critical-methodological and legal-propositional methods were used, from hermeneutic eye to a critical analysis capable of orienting the proposed microsystem. Concluding, in the end, for practical need of its application as a way to protect and promote dignity of the human person.

Keywords: Effectiveness; Environmental Labor Law; labor-environmental pollution; labor-environmental protection; objective civil responsibility. 


\section{INTRODUÇÃO}

O Estado Democrático de Direito em que se assenta a República Federativa do Brasil segundo soberania popular na qual se assenta o Poder Constituinte Originário, à forja da Constituição de 1988, dita Cidadã, fez a opção pelo princípio da inafastabilidade da jurisdição, de modo que cabe ao Poder Judiciário, em toda e qualquer situação, dar a palavra decisória final.

Como palavra é signo, aberta a interpretação, inclusive por mutação, na qual a semântica do texto é alterada, mudando-se o sentido sem que se mudem propriamente as palavras, aos magistrados, em geral, cabe engendrar uma hermenêutica adequada que resguarde e promova a dignidade da pessoa humana.

À Justiça do Trabalho, por delegação constitucional, cabe processar e julgar as ações oriundas das relações de trabalho. Porém, em casos de danos ao meio ambiente do trabalho, os juízes trabalhistas não têm conferido hermenêutica adequada, mormente nos casos em que se perquire a responsabilidade civil-trabalhista do empregador-poluidor.

Assim, a partir do critério metodológico de abordagem crítico-metodológica e jurídico-propositiva, este trabalho lança um olhar sobre a hermenêutica da legislação, a partir da Constituição da República Federativa do Brasil e de tratados internacionais de direitos humanos ratificados pelo Brasil, para propor um microssistema autônomo e independente de Direito Ambiental do Trabalho, com conteúdo particularmente ambiental e conteúdo particularmente trabalhista, em interseção de direitos sociais-ambientais, que reconheça a responsabilidade civil objetiva do empregador por danos ao meio ambiente do trabalho.

Como já reconhece o STJ em questões ambientais, a responsabilidade por dano ao meio ambiente do trabalho é objetiva, informada pela teoria do risco integral, sendo o nexo de causalidade o fator aglutinante que permite que o risco se integre na unidade do ato, não se admitindo excludentes da responsabilidade civil para afastar sua obrigação de indenizar.

Essa interpretação, ao proteger a vítima, é mais adequada ao objetivo fundamental da República de construir uma sociedade justa, fraterna e solidária e atende ao poder/dever do magistrado de resguardar e promover a dignidade da pessoa humana. 


\section{O PROBLEMA HERMENÊUTICO}

O Direito Ambiental é uma ciência complexa. Segundo Krell (2013, p. 2078), isso se dá pela "dependência científica e interdisciplinaridade, além da massiva incidência de conflitos de interesse, motivações econômicas e políticas na sua formulação e, mais ainda, na sua aplicação".

Embora a Constituição confira ao meio ambiente status de direito fundamental e, ao mesmo tempo, inclua no seu âmbito de proteção o meio ambiente do trabalho, a interpretação conferida no âmbito do Direito do Trabalho não se mostra adequada a essa premissa, mormente quando se constata que a análise material-processual não perpassa, adequadamente, a perspectiva ambiental.

O direito comum será fonte subsidiária do direito material do trabalho (art. $8^{\circ}, \S 1^{\circ}$, da CLT); nos casos omissos ${ }^{3}$, o direito processual comum será fonte subsidiária do direito processual do trabalho, exceto naquilo em que lhe for incompatível (art. 769 da CLT).

Essa abertura material-processual da CLT foi intencionada. Arnaldo Süssekind ${ }^{4}$ dizia que a CLT, forjada à luz do Código Civil de 1916 e do CPC de 1939, não teve a intenção de ser completa, em si mesma, mas de possuir lacunas colmatáveis a partir do direito comum e do diálogo com outras fontes.

Aliás, a normatividade, no geral, conterá inevitavelmente lacunas; "mesmo uma lei muito cuidadosamente pensada não pode conter uma solução para cada caso necessitado de regulação que seja atribuível ao âmbito de regulação da lei" (LARENZ, 1997, p. 519).

Por certo, porém, essa colmatação deve forjar a melhoria da condição social dos trabalhadores e promover avanço social, emparelhada com o princípio da dignidade da pessoa humana - a teor dos arts. $1^{\circ}$, III, e $7^{\circ}$, caput, da própria Constituição.

Outrossim, o art. $5^{\circ}$ da LINDB (decretada em 1942, anterior à própria CLT) diz que o juiz, na aplicação da lei, atenderá - leia-se, pela flexão do verbo no modo imperativo, que aí se encontra um poder/dever ${ }^{5}$ - aos fins sociais a que ela se dirige e às exigências do bem comum.

3 Embora não seja o foco do trabalho, registre-se que a "omissão" (lacuna) pode ser meramente legislativa, dada a inexistência de tratativa da regra especificamente na legislação trabalhista, mas pode, igualmente, ser ontológica ou axiológica, quando a norma trabalhista se encontrar superada no tempo ou, ainda, por não fazer jus a critérios valorativos de justiça.

4 Não se cita a fonte porque se trata de citação de memória, de uma entrevista vista, do célebre jurista, em algum momento da vida.

5 A expressão "poder/dever" é redundante, porque de todo poder emana um dever, uma função correspondente. O poder pelo poder, por si só, é incompatível com o Estado Democrático de Direito. 
$\mathrm{O}$ art. $8^{\circ}$ do CPC, ao aperfeiçoar o art. $5^{\circ}$ da LINDB, passa a dizer que o juiz, ao aplicar o ordenamento jurídico, atenderá aos fins sociais e às exigências do bem comum, resguardando e promovendo a dignidade da pessoa humana e observando a proporcionalidade, a razoabilidade, a legalidade, a publicidade e a eficiência.

Didier Júnior (2016, p. 76-77) bem coloca que há, no verbo promover, previsto no art. $8^{\circ}$ do CPC, "a exigência de um comportamento mais ativo do magistrado", de modo que, em algumas situações, o juiz poderá tomar, até mesmo de ofício, medidas para efetivar a dignidade da pessoa humana e "para a execução do direito fundamental à dignidade". De fato, essa promoção se dá, em última análise, pelo juiz, que detém a exclusividade da jurisdição (art. $5^{\circ}, \mathrm{XXXV}$, da Constituição).

Ainda, a norma, após a sua promulgação e eficácia jurídico-social, "irradia uma ação que lhe é peculiar, que transcende aquilo que o legislador tinha intentado". Como a norma "intervém em relações da vida diversas e em mutação, cujo conjunto o legislador não podia ter abrangido, e dá resposta a questões que o legislador ainda não tinha colocado a si próprio", ela "adquire, com o decurso do tempo, cada vez mais como que uma vida própria e afasta-se, deste modo, das ideias dos seus autores" (LARENZ, 1997, p. 446). Essa régua, certamente, perpassa a inafastabilidade da jurisdição.

A interpretação judicial deve ser criativa a ponto de indicar soluções possíveis, aos conflitos trabalhistas, forjadas no resguardo da promoção da dignidade da pessoa humana, e isso somente será possível à luz de uma adequada interpretação a partir do Direito Ambiental do Trabalho e da Constituição.

A partir dessas reflexões reside a proposta deste trabalho.

É cediço que a responsabilidade civil-trabalhista - a regra - é subjetiva, dada a dicção do art. $7^{\circ}$, XXVIII, da Constituição, segundo o qual o empregador estará obrigado a reparar o dano que, por ato ilícito, causar ao empregado, quando incorrer em dolo ou culpa.

Excepcionalmente, a Justiça do Trabalho tem reconhecido a responsabilidade objetiva, no âmbito laboral, mas limitada à norma-regra do art. 927, parágrafo único, do Código Civil, isto é, à obrigação de reparar o dano, independentemente de culpa, aos casos em que a atividade normalmente desenvolvida pelo empregador implicar, por sua natureza, risco aos direitos do empregado.

A chamada "Reforma Trabalhista", por meio da promulgação da 
Lei n. 13.467/2017, ao incluir o Título II-A na CLT, que trata do dano extrapatrimonial, em nada alterou essa formatação.

Entretanto, é igualmente cediço que, na velha solução às antinomias aparentes de normas, o critério da especialidade (lex specialis derogat legi generali) exsurge com a premissa de que norma especial revoga norma geral, o que demanda um olhar específico às questões labor-ambientais, mormente porque têm tratativa diferenciada na Constituição (arts. $6^{\circ}, 200$, VIII, e 225).

De outra banda, a própria Constituição, ao se constituir em um Estado Democrático de Direito destinado a assegurar o exercício de direitos sociais, do bem-estar, da igualdade e da justiça, como valores supremos, com vedação ao retrocesso social e a partir de uma cláusula de avanço social, com a busca contínua e incessante da melhoria da condição social dos trabalhadores, não limitou a responsabilidade civil-trabalhista aos casos em que houver dolo ou culpa, mas tão somente dispôs que a reparação civil constitui um núcleo mínimo, sem prejuízo de outras formatações que agreguem civilidade à condição humana.

Prova disso é que a aplicação do art. 927, parágrafo único, do Código Civil, que consagra a responsabilidade civil objetiva, é aplicável, de forma inconteste, ao Direito do Trabalho.

Nesse contexto de ideias, propõe-se mais um microssistema considerados os diversos microssistemas de responsabilidade civil objetiva -, específico à tutela labor-ambiental, destinado a tutelar, adequadamente, o meio ambiente do trabalho, considerada, nas palavras de Oliveira (2011, p. 142), a impossibilidade de se alcançar um patamar civilizatório mínimo de qualidade de vida sem a correspondente qualidade de vida no trabalho.

Com efeito, quando se fala em adequada tutela do meio ambiente do trabalho, essa adequação abrange o "aspecto repressivo da tutela labor-ambiental", que possui, dentre os diversos matizes, a indenização devida e decorrente da perpetração de danos morais ao trabalhador, "sendo que esta última decorre da evolução do instituto da responsabilidade civil" (CUNHA, 2015, p. 227). E o direito à saúde, na sua mais ampla acepção de sadia qualidade de vida, compreende a tutela integral do trabalhador na sua condição humana, cuja violação caracteriza um dano extrapatrimonial ${ }^{6}$.

6 "Promoção da saúde é o nome dado ao processo de capacitação da comunidade para atuar na melhoria de sua qualidade de vida e saúde, incluindo uma maior participação no controle deste processo. Para atingir um estado de completo bem-estar físico, mental e social os indivíduos e grupos devem saber identificar aspirações, satisfazer necessidades e modificar favoravelmente o meio ambiente. A saúde deve ser vista como um recurso para a vida, e não como objetivo de viver. Nesse sentido, a saúde é um conceito positivo, que enfatiza os recursos sociais e pessoais, bem como as capacidades físicas. Assim, a promoção da saúde não é responsabilidade exclusiva do setor saúde, e vai para além de um estilo de 


\section{DIREITOS SOCIAIS E DIREITO AMBIENTAL}

A Constituição de 1988 foi revolucionária ${ }^{7}$. Diferentemente das que lhe antecederam, ela fez uma opção e quis mostrar, desde o início, ideais e valores supremos que devem delineiam e formatam a concepção jurídica de Estado Democrático de Direito, visto "não como uma aposição de conceitos, mas sob um conteúdo próprio onde estão presentes as conquistas democráticas, as garantias jurídico-legais e a preocupação social" (STRECK; MORAIS, 2013, p. 113).

Nesse diapasão, já no Título I elenca aqueles que serão seus princípios fundamentais. A importância dos direitos sociais é inquestionável, seja na própria razão de existir da República, fundada na cidadania, na dignidade humana, nos valores sociais do trabalho e da livre iniciativa; seja em seus objetivos fundamentais, de construção de uma sociedade livre, justa e solidária, erradicação da pobreza e da marginalização, redução das desigualdades sociais e regionais e promoção do bem de todos; seja no reconhecimento, em nível global, da prevalência dos direitos humanos e do dever de cooperação entre os povos para o progresso da humanidade (arts. $1^{\circ}$, II, III e IV, $3^{\circ}$, I, III e IV, e $4^{\circ}$, II e IX, da Constituição).

Os direitos sociais têm relevo, em sua essência, no Capítulo II da Constituição, com o registro de que, por também fazerem parte do Título I, são igualmente considerados - no mesmo patamar valorativo do art. $5^{\circ}$ - direitos e garantias fundamentais, de aplicação imediata (art. $5^{\circ}, \S 1^{\circ}$ ), "de tal sorte que todas as categorias de direitos fundamentais estão sujeitas, em princípio, ao mesmo regime jurídico" (SARLET, 2013a, p. 514-515).

O Poder Constituinte pôs "a proteção social como um dos direitos humanos cuja garantia é a própria Lei Maior" (BALERA, 1989, p. 17).

Os direitos sociais têm em seu favor o princípio da vedação ao retrocesso social, bem explicitado na cabeça do art. $7^{\circ}$ da Constituição, "a coibir medidas de cunho retrocessivo" que "venham a desconstituir ou afetar gravemente o grau de concretização já atribuído a determinado direito fundamental (e social), o que equivaleria a uma violação à própria Constituição Federal" (SARLET, 2013b, p. 542-543).

Porém, o ordenamento jusconstitucional não se satisfaz com a simples vedação ao retrocesso social, considerada a necessidade premente da vida,

vida saudável, na direção de um bem-estar global." (Carta de Ottawa - I Conferência Internacional sobre Promoção da Saúde).

7 Revolucionária, mas tardia. Jellinek (2015, p. 95), ao comentar a Declaração dos Direitos do Homem e do Cidadão (França, 1789), em compasso com outros atos constitucionais da época, disse o seguinte: "Em todas essas Constituições, a declaração de direitos ocupa o primeiro lugar. Somente em segundo lugar vem juntar-se o plano ou o quadro de governo". 
de se caminhar para frente, de evoluir, de agir, de tornar efetiva a promessa constitucional uma sociedade livre, justa e solidária. Nesse sentido, o art. $7^{\circ}$ da Constituição consagra autêntica "cláusula de avanço social", quando elenca direitos mínimos além de outros que visem à melhoria da condição social dos trabalhadores.

Segundo o STF, “o princípio da proibição do retrocesso impede, em tema de direitos fundamentais de caráter social, que sejam desconstituídas as conquistas já alcançadas pelo cidadão ou pela formação social em que ele vive"".

Essa também é a ideia consagrada no Pacto Internacional sobre Direitos Econômicos, Sociais e Culturais, que ostenta posição hierárquico-normativa de supralegalidade no ordenamento jurídico brasileiro e traz, formal e materialmente, a noção de progressividade dos direitos sociais.

Com a ratificação do Pacto (Decreto n. 591/1992), “o Brasil se comprometeu a implementar, progressivamente e com o máximo de seus recursos disponíveis, os direitos ligados à igualdade", a extrair do princípio de vedação ao retrocesso social "um vetor dinâmico e unidirecional positivo, que impede a redução do patamar de tutela já conferido à pessoa humana" (BONNA, 2008, p. 60).

Conforme art. 225, caput, da Constituição, todos têm direito a um meio ambiente ecologicamente equilibrado, bem de uso comum do povo e essencial à sadia qualidade de vida, impondo-se ao Poder Público e à coletividade o dever de defendê-lo e preservá-lo para presentes e futuras gerações.

É pacífico o reconhecimento de que se trata de um autêntico direito fundamental (KRELL, 2013, p. 2078), inclusive por força do art. $5^{\circ}, \S 2^{\circ}$, da Constituição - cláusula de abertura material -, ao explicitar que os direitos e garantias lá expressos não excluem outros decorrentes do regime e dos princípios por ela adotados, o que permite ao hermeneuta constitucional, em uma leitura sistemática e sistêmica, adequada à dignidade da pessoa humana, reconhecer que o rol de direitos fundamentais não é taxativo, numerus clausus, mas tão somente meramente exemplificativo e aberto, numerus apertus.

O objeto de proteção do art. 225 da Constituição não se revela somente em seus espectros natural (ar, água, solo, flora, fauna), artificial (estética da

8 Recurso Extraordinário com Agravo n. 639.337 AgR/SP, Relator: Ministro Celso de Mello, Órgão Julgador: $2^{\mathrm{a}}$ Turma, Julgamento: 23.8.2011, Publicação: DJe divulgado em 14.9.2011 e publicado em 15.9.2011; no mesmo sentido, Recurso Extraordinário n. 581.352 AgR/AM, Relator: Ministro Celso de Mello, Órgão Julgador: $2^{\mathrm{a}}$ Turma, Julgamento: 29.10.2013, Publicação: DJe divulgado em 21.11.2013 e publicado em 22.11.2013. 
paisagem e o ambiente construído pelo homem) e cultural (KRELL, 2013, p. 2079), mas, igualmente, o meio ambiente do trabalho, como bem quis a própria Constituição, que enuncia, no art. 200, VIII, que na proteção do meio ambiente se compreende "o do trabalho".

A Constituição "estabeleceu expressamente que a ordem econômica deve observar o princípio da defesa do meio ambiente" (OLIVEIRA, 2011, p. 142), na esteira do art. 170, VI, para o qual a ordem econômica, fundada na valorização do trabalho humano e na livre iniciativa ${ }^{9}$, tem por fim assegurar a todos existência digna, conforme os ditames da justiça social, observados o princípio da defesa do meio ambiente, nele incluído o do trabalho.

Nessa perspectiva, a Constituição, como gênese do Direito Ambiental brasileiro, tendo adotado modelo intervencionista do Estado, "busca o efetivo cumprimento de uma economia fundada na valorização do trabalho humano", o que, por si só, não constitui enunciado meramente descritivo "e sim uma norma condicionadora que estabelece os alicerces, os fundamentos da ordem econômica brasileira" (FIORILLO, 2013, p. 1815).

Se o art. 170, VI, da Constituição estabelece a defesa do meio ambiente (nele incluído o do trabalho) como um "princípio geral da atividade econômica" e busca "a satisfação dos preceitos fundamentais" descritos no art. $1^{\circ}$ (FIORILLO, 2013, p. 1815), por certo, além do art. $5^{\circ}, \S 2^{\circ}$ (abertura material da Constituição), resta evidente o nível de fundamentalidade do meio ambiente (do trabalho), que se mostra entrelaçado aos direitos sociais trazidos, exemplificadamente, nos arts. $6^{\circ}$ e $7^{\circ}$ da Constituição.

Com efeito, "é impossível alcançar qualidade de vida sem ter qualidade de trabalho [e] nem se pode atingir meio ambiente equilibrado e sustentável ignorando o meio ambiente do trabalho" (OLIVEIRA, 2011, p. 142). Nessa perspectiva, "o problema da tutela jurídica do meio ambiente manifesta-se a partir do momento em que a degradação passa a ameaçar não só o bem-estar, mas a qualidade da vida humana, senão a própria sobrevivência do ser humano" (SILVA, 2000 apud OLIVEIRA, 2011, p. 142).

De fato, é impossível alcançar a melhoria da condição social dos trabalhadores, com a preservação e expansão dos direitos sociais, sem uma adequada higidez do meio ambiente do trabalho, diretamente ligado à condição humana. Trata-se, inclusive, da perspectiva "transfronteiriça"

9 Embora o art. 170, caput, da Constituição fale apenas em "livre iniciativa", registre-se que o art. $1^{\circ}$, IV, afirma que a República, ao se constituir em Estado Democrático de Direito, tem como fundamentos, entre outros, os valores sociais do trabalho $e d a$ livre iniciativa. Não disse valores sociais do trabalho $e$ livre iniciativa, o que demanda concluir que, com o uso da preposição, a Constituição pretendeu imprimir ineficácia à livre iniciativa que se mostre destituída de valores sociais. 
da dimensão biopsicossocial ${ }^{10}$ : o meio ambiente do trabalho é matéria de ordem pública, de interessa de toda a coletividade, e produz repercussão dentro e fora do meio ambiente do trabalho.

Da tríade da biopsicossocialidade - biologia, psicologia e socialidade -, o meio ambiente do trabalho deve ser visto a partir de uma visão multidimensional, capaz de compreender todas as suas causalidades, fruto do princípio da "primazia da análise contextual de causalidades". Nessa esteira, o processo de coletivização de direitos não apenas perpassa os direitos sociais, de segunda geração, como "continua a se manifestar até o reconhecimento de direitos de natureza difusa, como o direito ao meio ambiente" (PADILHA, 2011, p. 238).

\subsection{Interdependência entre direitos sociais e ambientais}

Conforme escólio de Sarlet e Fensterseifer (2012 apud BRITO; ZUBERI; BRITO, 2018, p. 71), a abordagem constitucional do direito ambiental perpassa uma dupla funcionalidade, ao que Sampaio (2016 apud BRITO; ZUBERI; BRITO, 2018, p. 71) chama de segundo ciclo do constitucionalismo ecológico, "por superar o tradicional caráter programático da norma constitucional ambiental e agregar o significado jusfundamental".

Como assevera Fensterseifer (2008 apud BRITO; ZUBERI; BRITO, 2018, p. 71), o espectro material de fundamentalidade do direito ambiental se dá pela ligação direta com a dignidade da pessoa humana; o direito ao meio ambiente não está inserto formalmente no rol de direitos e garantias fundamentais, na Constituição, mas ainda assim carrega a dimensão (material) de direito fundamental.

$\mathrm{Na}$ esteira do constitucionalismo ecológico, "surgem, como reivindicação mundial e existencial, questionamentos acerca da edificação de um Estado de Direito Socioambiental", forjado a partir da "compatibilidade axiológica entre homem e meio ambiente embaraçados em um futuro comum” (MORAIS; SARAIVA, 2018, p. 13).

Esse entremear "impõe a imprescindibilidade de se alinhar a questão social à questão ambiental” (MORAIS; SARAIVA, 2018, p. 17). Segundo

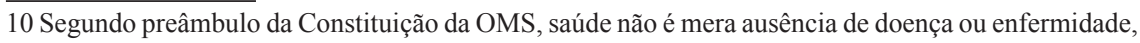
mas um completo estado de bem-estar físico, mental e social, daí sua projeção biopsicossocial. Tal preceito é reiterado, formalmente, no art. $3^{\circ}$, "e", da Convenção n. 155 da OIT, ostentando essa última posição hierárquico-normativa de supralegalidade, de modo que qualquer legislação de cunho infraconstitucional/legal que lhe contraponha sofre eficácia paralisante. 
Ulrich Beck, "os problemas ambientais são - na origem e nos resultados - sociais, problemas do ser humano, de sua história, de suas condições de vida, de sua relação com o mundo e com a realidade, de sua constituição econômica, cultural e política" (LEAL; ROCHA, 2018, 267).

De fato, um dos pilares normativos representativo de direitos humanos advindos do pós-guerra, a fim de normatizar a Declaração Universal de Direitos Humanos e lhe imprimir caráter vinculante, foi o Pacto Internacional sobre Direitos Econômicos, Sociais e Culturais, em 1966. Esse tratado internacional de direitos humanos, ratificado pelo Governo brasileiro consoante Decreto n. 591/1992, ostenta posição hierárquico-normativa de supralegalidade.

O Pacto reconhece o direito de toda pessoa de desfrutar o mais elevado nível possível de saúde física e mental e impõe, para tanto, medidas que os Estados-Partes deverão adotar, com o fim de assegurar o pleno exercício desse direito, entre elas a melhoria de todos os aspectos de higiene do trabalho e do meio ambiente (artigo 12).

A Lei n. 6.938/1981, que dispõe sobre a Política Nacional do Meio Ambiente, seus fins e mecanismos de formulação e aplicação e dá outras providências, prevê (artigo $3^{\circ}$ ) que meio ambiente é "o conjunto de condições, leis, influências e interações de ordem física, química e biológica, que permite, abriga e rege a vida em todas as suas formas", degradação da qualidade ambiental "a alteração adversa das características do meio ambiente" e poluição, entre outros, é a "degradação da qualidade ambiental resultante de atividades que direta ou indiretamente criem condições adversas às atividades sociais e econômicas".

Nesse sentido, o poluidor é a pessoa natural ou jurídica, de direito público ou privado, responsável, direta ou indiretamente, por atividade causadora de degradação ambiental, nela incluída o meio ambiente do trabalho (art. $3^{\circ}$, IV, da Lei n. 6.938/1981).

Bem colocou o então Senador Cristovam Buarque, ao propor a Proposta de Emenda à Constituição (PEC) n. 16/2012, que propunha alterar a redação do art. $6^{\circ}$ da Constituição para incluir expressamente, entre os direitos sociais, o "meio ambiente saudável", a par do que já foi aqui exposto:

No artigo 225 e em outras normas constitucionais, de forma expressa ou implícita, sob a ótica do Direito Ambiental, essa questão é interpretada como um dos direitos fundamentais da pessoa humana e um bem de uso comum do povo e essencial à sadia qualidade de vida de todos, o que reforça a posição de que se trata também de direitos 
humanos e sociais. Por esta razão, nada mais natural do que explicitar que o meio ambiente saudável esteja também listado como um Direito Social assegurado pela Constituição Federal (BRASIL, 2012).

Bem lembrou Sua Excelência que o Capítulo VI, que trata do Meio Ambiente, insere-se no Título VIII, que cuida da Ordem Social, "o que faz concluir que o meio ambiente é também um direito social do homem" (BRASIL, 2012).

Lamentavelmente, a Proposta foi arquivada ao final da Legislatura de 2018.

Entretanto, o meio ambiente permanece, de forma implícita, inserido na inteligência do art. $6^{\circ}$ da Constituição.

A Lei n. 9.795/1999, que dispõe sobre a educação ambiental, institui a Política Nacional de Educação Ambiental e dá outras providências, bem coloca a questão aqui travada, de interdependência entre direitos sociais e ambientais, numa comunhão protetiva ao meio ambiente do trabalho.

Segundo art. $4^{\circ}$ da citada Lei, são princípios básicos da educação ambiental, entre outros, o enfoque humanista, holístico, democrático e participativo, a concepção do meio ambiente em sua totalidade, considerando a interdependência entre o meio natural, o socioeconômico e o cultural, sob o enfoque da sustentabilidade, e a vinculação entre a ética, a educação, o trabalho e as práticas sociais.

\subsubsection{Meio ambiente natural, artificial e cultural (e do trabalho)}

Segundo Silva (1998), o meio ambiente pode ser conceituado como "a interação do conjunto de elementos naturais, artificiais e culturais que propiciem o desenvolvimento equilibrado da vida em todas as suas formas", podendo ser classificado em meio ambiente natural, que inclui as águas, o solo, o ar, a flora, a fauna e outras representatividades da natureza; o meio ambiente artificial, como ruas, praças e espaços urbanos, abertos e fechados, sujeitos à criação, alteração, modificação ou aformoseamento por meio da atividade humana; o meio ambiente cultural, que inclui nosso patrimônio histórico, artístico e paisagístico; e, finalmente, o meio ambiente do trabalho, representativo das relações entre os trabalhadores e o meio físico, incluído o local de trabalho, as ferramentas de trabalho e os agentes físicos, químicos e biológicos aos quais o obreiro está exposto.

Já na década de 1950, com o ambientalismo científico (BIRNFELD, 1998), engendrou-se a questão ambiental com as consequências 
advindas das revoluções industriais e a própria revolução do trabalho. A evolução científica e o refinamento social tornaram, ao longo do tempo, inquestionável a inclusão do meio ambiente do trabalho dentro do espectro labor-ambiental.

Sobre a relevância jusambiental, produzida pela própria Constituição da República Federativa do Brasil, conforme já aqui exposto, enquanto "expressão da soberania popular", a imprimir "autonomia dogmática do ente meio ambiente do trabalho" e autenticar "a integração jurídica do meio ambiente laboral ao meio ambiente humano, inserindo-o dentre as dimensões passíveis de identificação no plexo ambiental", leciona Maranhão (2018, p. 291):

Ora, a proteção jusambiental, em essência, guarda ligação direta com o duplo e integrativo compromisso de resguardar o equilíbrio ecológico e proteger a vida humana. Nessa visão, o meio ambiente natural, que induz preocupação primária com a esgotabilidade dos componentes naturais, recebe proteção por ser o próprio âmago desse perseguido equilíbrio ecológico. Já o meio ambiente artificial atrai preocupação primária ligada ao resguardo da utilidade de componentes construídos para facilitar a segura e saudável habitação e circulação humanas, estando mais vinculado, portanto, à questão da qualidade da vida humana. O mesmo se pode dizer do meio ambiente cultural, para o qual a preservação da singularidade da exteriorização psicossensorial e social do criativo espírito humano se apresenta como fator decisivo de preocupação. O meio ambiente laboral, nesse contexto, exsurge como dimensão ambiental deveras diferenciada, na medida em que apta a propiciar, em paralelo, o resguardo do equilíbrio ecológico e a preservação da vida humana. Realmente, a proteção do meio ambiente do trabalho é medida que atinge, a um só tempo, a ambos os citados objetivos, ou seja, tanto serve à proteção do ser humano investido no papel social de trabalhador quanto à proteção da população vizinha e do equilíbrio ecológico que o circunda. É essa visão mais ampla e integrada, a conferir ao tema estatura de questão de saúde pública, como genuíno interesse público primário, que precisa impregnar a mente do estudioso jusambiental.

É dentro da preocupação com esse "giro hermenêutico", apto a fomentar a autonomia científica do Direito Ambiental do Trabalho e a verificação da responsabilidade do empregador-poluidor do meio ambiente do trabalho, na perspectiva do Direito do Trabalho e do Direito Ambiental, que se forja o presente trabalho. 


\section{MICROSSISTEMAS DE RESPONSABILIDADE CIVIL OBJETIVA}

O ordenamento deve ser pensado a partir de um regramento de justiça, de natureza valorativa, de modo que o sistema a ele (ao ordenamento) correspondente só pode ser uma ordenação axiológica ou teleológica.

De "teleológico" não se extrai apenas a noção básica do significado, isto é, no sentido estrito de pura conexão de meios aos fins, em um raciocínio meramente cartesiano (qual a norma posta e quais os fins da norma). De teleológico se extrai, também, o seu sentido mais abrangente, de realização de escopos e valores (CANARIS, 2002, p. 66-67).

Nesse diapasão, a responsabilidade civil é importante instrumento de realização de escopos e valores, mormente em nosso Estado Democrático de Direito, no qual constitui objetivo fundamental da República, entre outros, o de construir uma sociedade livre, justa e solidária (art. $3^{\circ}$, I, da Constituição). Como bem ressalta Stoco (2004, p. 118), a imposição de responsabilizar o ofensor, por seus atos, e do dever de indenizar "traduz a própria noção de justiça existente no grupo social" e se revela "como algo inarredável da natureza humana".

A reparação se volta ao prejuízo injustamente perpetrado à vítima pelo ofensor, à semelhança do direito francês: "Il a déjà été souligné que le droit de la responsabilité civile en France, comme d'ailleurs dans la plupart des pays étrangers, est orienté principalement vers la réparation des dommages qui constitue son objectif prioritaire" (VINEY; JORDAIN, 2010, p. 154). Para Cretella Júnior (1980, p. 5 apud STOCO, 2004, p. 129), os pressupostos da responsabilidade são os seguintes:
a) aquele que infringe a norma;
b) a vítima da quebra;
c) o nexo causal entre o agente e a irregularidade;
d) o prejuízo ocasionado - o dano - a fim de que se proceda à reparação, ou seja, tanto quanto possível, ao reingresso do prejudicado no status econômico anterior ao da produção do desequilíbrio patrimonial.

Santos (2015, p. 28) registra a responsabilidade civil, sinteticamente, como "a obrigação de responder pelas consequências jurídicas decorrentes de ato ilícito praticado, reparando o prejuízo ou dano causado".

A responsabilidade civil pode ser contratual ou extracontratual (aquiliana). Lembra Stoco (2004, p. 136) que o Código Civil distinguiu a responsabilidade contratual, "ao disciplinar os defeitos do negócio jurídico" 
(arts. 166 a 184 do Código Civil), da extracontratual, "ao conceituar o ato ilícito" (art. 186 do Código Civil).

A responsabilidade civil contratual, segundo Aguiar Dias (1979, p. 148-149 apud STOCO, 2004, p. 137), correspondente à "inexecução previsível e evitável, por uma parte ou seus sucessores, de obrigação nascida de contrato prejudicial à outra parte ou seus sucessores".

A responsabilidade civil extracontratual "escapa às regras próprias dos contratos":

[...] é certo que a responsabilidade extracontratual se funda na autonomia da vontade, ao passo que a responsabilidade extracontratual independe dela. [...] a responsabilidade contratual obedece às regras comuns dos contratos e, frequentemente, baseia-se em dever de resultado, o que acarreta a presunção de culpa. (AGUIAR DIAS, 1979, p. 148-149 apud STOCO, 2004, p. 137)

Sinteticamente, Santos (2015, p. 28) registra ser a responsabilidade civil contratual aquela decorrente do próprio contrato ou extracontratual a "que se traduz na violação de um preceito de lei, sem conexão com a norma contratual".

Particularmente, entende-se pelo desacerto dessa lógica dicotômica. Stoco (2004, p. 137) resgata essa advertência:

Caio Mário adverte não ter razão os que procuram encontrar distinção ontológica entre culpa contratual e culpa aquiliana. Uma e outra apresentam pontos diferenciais no que diz respeito à matéria de prova e à extensão dos efeitos. São, porém, aspectos acidentais. O que sobreleva é a unicidade ontológica. Numa e noutra, há de estar presente a contravenção a uma norma, ou, como se exprime Pontes de Miranda: "a culpa é a mesma para infração contratual e para delitual”.

Tal unicidade ontológica sobreleva ainda mais no âmbito do Direito do Trabalho: ao lado dos efeitos próprios do contrato de trabalho, inegavelmente, tem-se efeitos conexos:

O contrato de trabalho é ato jurídico de conteúdo complexo, hábil a provocar larga multiplicidade de direitos e obrigações entre as partes pactuantes. Há efeitos obrigacionais incidentes sobre a figura do empregador, assim como incidentes sobre a figura do empregado. Os efeitos resultantes do contrato de trabalho podem ser classificados em duas grandes modalidades, segundo sua vinculação mais ou menos direta ao conteúdo contratual trabalhista: efeitos próprios ao contrato e efeitos conexos ao contrato de trabalho.

Próprios são os efeitos inerentes ao contrato empregatício, por decorrerem de sua natureza, de seu objeto e do conjunto natural e recorrente das cláusulas contratuais trabalhistas. São repercussões obrigacionais inevitáveis à estrutura e dinâmica do 
contrato empregatício ou que, ajustadas pelas partes, não se afastam do conjunto básico do conteúdo do contrato. As mais importantes são, respectivamente, a obrigação de o empregador pagar parcelas salariais e a obrigação de o empregado prestar serviços ou colocar-se profissionalmente à disposição do empregador. Conexos são os efeitos resultantes do contrato empregatício que não decorrem de sua natureza, de seu objeto e do conjunto natural e recorrente das cláusulas contratuais trabalhistas, mas que, por razões de acessoriedade ou conexão, acoplam-se ao contrato de trabalho. Trata-se, pois, de efeitos que não têm natureza trabalhista, mas que se submetem à estrutura e dinâmica do contrato de trabalho, por terem surgido em função ou em vinculação a ele (DELGADO, 2018, p. 725).

Outrossim, na lógica dos efeitos do contrato de trabalho, certo é que existem deveres anexos ao contrato, inclusive com substancial impacto em normas de higiene, saúde, segurança e medicina do trabalho, melhor dizer, com exigência direta, diante e decorrente do próprio contrato de trabalho, de que o empregador mantenha a higidez dos seus trabalhadores, vista no aspecto da biopsicossocialidade, conforme preâmbulo da Constituição da OMS e art. 30, "e", da Convenção n. 155 da OIT (a última com posição hierárquico-normativa de supralegalidade), para as quais saúde não é mera ausência de doença ou enfermidade, mas um completo estado de bem-estar físico, mental e social.

A constatação da culpa da reclamada emergiu da sua conduta negligente, pois não comprovou o implemento das necessárias medidas preventivas exigidas pela ordem jurídica em matéria de segurança e saúde no trabalho, deveres anexos ao contrato de trabalho. Portanto, a reclamada, ao não se desincumbir de tal ônus probatório, acarretou a presunção de culpa e a consequente responsabilização pelo dano causado. Não configuradas as violações apontadas. Recurso não conhecido (TST; RR 15070086.2005.5.05.0021; 6 ${ }^{\mathrm{a}}$ T.; Rel. Min. Mauricio Godinho Delgado; DEJT 29.10.2010; p. 1.150) (DALLEGRAVE NETO, 2016, p. 73).

Porém, para fins didáticos, adota-se a classificação clássica ${ }^{11}$.

A par da responsabilização contratual e extracontratual, a responsabilidade civil pode ser subjetiva ou objetiva, especialmente ligada à ideia de presença ou ausência de culpa (ou, de modo agravado, o dolo).

11 Ainda assim, a classificação clássica não deixa de ser passível de críticas. Cita-se, por exemplo, a ADC n. 16/DF, julgada pelo STF, no qual a Corte entendeu que o art. $37, \S 6^{\circ}$, da Constituição trata "apenas" da responsabilidade contratual, não abarcando as situações da responsabilidade aquiliana (extracontratual), o que deixa de fora do âmbito de proteção do Direito, à sua quase totalidade, os trabalhadores terceirizados pela Administração Pública/tomadora dos serviços, que ficam adstritos à violação da contratualidade perante o empregador direto (o que demonstra que essa dicotomia não impacta direitos sociais fundamentais dos trabalhadores apenas na seara acadêmica, mas, igualmente, no mundo fenomênico). 
Stoco (2004) critica a falta de sistematização da culpa, no direito civil, a par do direito penal, que lhe sistematizou favoravelmente. Lembra ainda que, no direito civil, ainda prevalece a teoria psicológica da culpabilidade, já superada pelo direito penal, que lhe reconhece a partir da teoria normativa da culpabilidade.

Segundo Stoco (2004, p. 132) o dolo "é a vontade dirigida a um fim ilícito; é um comportamento consciente voltado à realização de um desiderato".

A culpa em sentido estrito, por sua vez, "traduz o comportamento equivocado da pessoa, despida da intenção de lesar ou violar direito, mas da qual poderia exigir-se comportamento diverso" (STOCO, 2004, p. 132).

A culpa é "erro inescusável ou sem justificativa plausível e evitável para o homo medius" (STOCO, 2004, p. 132). A título probatório, isto é, da prova da culpa em juízo, tendo em vista que é comportamento evitável pelo homem médio, faz-se por presunção, na medida em que o art. 375 do CPC prevê que o juiz aplicará as regras de experiência comum subministradas pela observação do que ordinariamente acontece.

O Código Civil de 2002 não se mostra alheio a essa realidade. Pelo contrário, embora tenha adotado e mantido a culpa como pressuposto da responsabilidade civil, ou seja, exigindo que a conduta tenha um qualificativo ligado ao elemento subjetivo ou interno da pessoa, de modo que há de projetar-se em direção a um resultado querido ou assumido, excepcionou esse princípio para, como exceção, admitir a responsabilidade independentemente de culpa (objetiva) quando a atividade desenvolvida pelo autor do dano implicar risco para os direitos de outrem (artigo 927, parágrafo único) (STOCO, 2004, p. 130).

Assim, resumidamente, a responsabilidade civil subjetiva leva em consideração o trinômio conjugado de: (i) ato danoso mais (ii) nexo de causalidade entre esse ato e o infortúnio suportado pela vítima mais (iii) o dolo ou a culpa; a responsabilidade civil objetiva dispensa esse último (dolo ou culpa).

Considerando esses termos, tem-se que a Constituição tratou, como regra, a responsabilidade subjetiva, na forma do art. $7^{\circ}$, XXVIII, quando trata da indenização a que está obrigado o empregador "quando incorrer em dolo ou culpa".

No entanto, a mesma Constituição reconhece a possibilidade de responsabilização na forma objetiva, sem perquirição de dolo ou culpa, como se vê, por exemplo, dos danos nucleares (art. 21, XXIII, "d"), da responsabilidade extracontratual da Administração Pública (art. 37, § $6^{\circ}$ ) e dos danos de natureza ambiental (art. 225, $\S 3^{\circ}$ ). 
Ademais, não se olvide que, além do art. $7^{\circ}$, caput, da Constituição consagrar a vedação ao retrocesso social, característica marcante dos direitos sociais ${ }^{12}$, certo é que, quando a Constituição fala em "além de outros", também consagra a necessidade premente da vida de se caminhar para frente, de evoluir, de agir, de tornar efetiva a promessa constitucional uma sociedade livre, justa e solidária.

Nesse sentido, a Constituição consagra autêntica "cláusula de avanço social”, que orienta o não apenas o intérprete, mas o legislador, em especial, a progressivamente ampliar o rol de direitos mínimos (o Pacto Internacional sobre Direitos Econômicos, Sociais e Culturais, por exemplo, garante progressividade a tais direitos).

Nesse diapasão, a responsabilidade objetiva dá mais proteção ao trabalhador, em especial o trabalhador-empregado, com vínculo de emprego, seja pelo poder empregatício a que é submetido (poder diretivo, regulamentar, fiscalizatório e disciplinar), seja pela característica de alteridade do Direito do Trabalho, segundo a qual deve o empregador suportar os riscos do negócio (art. $2^{\circ}$, caput, da CLT).

Assim, a par de já prever que aquele que, por ação ou omissão voluntária, negligência ou imprudência, viola direito e causa dano a outrem, ainda que exclusivamente moral, ou, ao exercê-lo, excede manifestamente os limites impostos pelo seu fim econômico ou social, pela boa-fé ou pelos bons costumes, comete ato ilícito (arts. 186 e 187 do Código Civil), ficando obrigado a repará-lo (art. 927, caput, do Código Civil), tem-se ainda a obrigação de reparar o dano independentemente de culpa, na forma de cláusula geral codificada, consoante art. 927, parágrafo único, do Código Civil.

Segundo Molina (2013,p. 77), entre os vários textos legais que preveem a responsabilidade civil objetiva (sem a necessidade de se perquirir o dolo ou a culpa), "nos mostra que essa última modalidade se trata, na verdade, de um grande gênero", dito macrossistema de responsabilidade civil objetiva, "dentro do qual se inserem diversas espécies de responsabilidade civil sem culpa, conforme cada um dos microssistemas e da cláusula geral do art. 927, parágrafo único, do Código Civil”.

12 É o chamado "efeito cliquet", de modo que, uma vez reconhecido, o direito dito humano não pode ser tolhido ou reduzido: "A vedação ao retrocesso social também pode ser reconhecida na expressão francesa effet cliquet. O efeito cliquet é uma expressão utilizada no alpinismo para representar o movimento de ascensão que só permite ao alpinista subir" (LEITÃO; MEIRINHO, 2016, p. 43, grifo dos autores). 
Existem, atualmente, nove microssistemas de responsabilidade civil objetiva:

1. Acidente nuclear (art. 21, XXIII, da Constituição e Lei n. 6.453/1977).

2. Acidente ambiental (arts. $225, \S 3^{\circ}$, da Constituição e $14, \S 1^{\circ}$, da Lei n. 6.938/1981).

3. Acidente de transporte (arts. 734 e seguintes do Código Civil).

4. Empregados públicos e das pessoas jurídicas de direito privado prestadoras de serviços públicos (art. 37, § $6^{\circ}$, da Constituição).

5. Acidente em razão de ruína de edifício ou construção (art. 937 do Código Civil).

6. Acidente em razão de objetos candentes (art. 938 do Código Civil).

7. Acidente causado por animais (art. 936 do Código Civil).

8. Acidente nas atividades de mineração (Decreto-Lei n. 227/1967).

9. Acidente nas atividades de risco - cláusula geral codificada (art. 927, parágrafo único, do Código Civil).

Pretende-se, com este trabalho, é pensar um novo critério de responsabilidade civil objetiva, decorrente da adequada tutela labor-ambiental. A proposta se adéqua, inclusive, à tendência atual de "objetivação" da responsabilidade civil.

Com efeito, como se viu, a regra era a responsabilidade subjetiva, com previsão excepcional do regramento objetivo. Porém, é possível hoje, com a previsão da responsabilidade objetiva positivada por meio de uma cláusula geral, que permite a discricionariedade e equidade nos julgamentos, por parte do juiz, que responsabilidades subjetiva e objetiva convivam harmoniosamente.

A tendência atual, de "objetivação" da responsabilidade civil, ocorre pela preocupação maior do sistema de justiça (ordenado por valores e voltado à concretização de escopos constitucionais, de dignidade, solidariedade e igualdade material) com quem é a vítima, com quem efetivamente foi lesionado.

Doutrinariamente, Gagliano e Pamplona Filho (2003, p. 28-29 apud STOCO, 2004, p. 133) bem explicitam que a culpa é "elemento meramente acidental da responsabilidade civil", porque lhe "falta o necessário cunho de generalidade", nesses termos:

A culpa não é, em nosso entendimento, pressuposto geral da responsabilidade civil, sobretudo no novo Código Civil. [...] A culpa, portanto, não é elemento essencial, mas sim acidental, pelo que reiteramos nosso entendimento de que os elementos básicos ou pressupostos gerais da responsabilidade civil são apenas três: a conduta humana (positiva ou negativa), o dano ou prejuízo e o nexo de causalidade. 
Resgatando a crítica de Stoco (2004, p. 132), de falta de sistematização da culpa, no direito civil, a par do direito penal, registre-se que, na seara penal, a teoria geral do crime abarca o fato típico, a antijuridicidade e a culpabilidade, sendo que a antijuridicidade (ilicitude) espelha "a relação de contrariedade entre o fato típico e o ordenamento jurídico como um todo" (CUNHA, 2019, p. 297) e a culpabilidade um "juízo de reprovação [...] relativo à necessidade de aplicação da sanção penal” (CUNHA, 2019, p. 329).

Quanto ao Direito Civil, Catalan (2011), ao prenunciar a "morte" da culpa, destaca que o Direito, enquanto ciência prescritiva - e não meramente descritiva -, deve subsumir os comportamentos que destoem do ordenamento jurídico à ideia de antijuridicidade (ilicitude) e a culpa à violação de um dever de conduta.

Outrossim, à "objetivação" da responsabilidade caminha a jurisprudência nacional (BRASIL, 2013):

Sempre que demonstrada a ocorrência de ofensa injusta à dignidade da pessoa humana, dispensa-se a comprovação de dor e sofrimento para configuração de dano moral. Segundo doutrina e jurisprudência do STJ, onde se vislumbra a violação de um direito fundamental, assim eleito pela CF, também se alcançará, por consequência, uma inevitável violação da dignidade do ser humano. A compensação nesse caso independe da demonstração da dor, traduzindo-se, pois, em consequência in re ipsa, intrínseca à própria conduta que injustamente atinja a dignidade do ser humano. Aliás, cumpre ressaltar que essas sensações (dor e sofrimento), que costumeiramente estão atreladas à experiência das vítimas de danos morais, não se traduzem no próprio dano, mas têm nele sua causa direta. REsp 1.292.141-SP, Rel. Min. Nancy Andrighi, julgado em 4/12/2012. Informativo n. 513 do STJ.

O microssistema aqui proposto, a partir da adequada tutela labor-ambiental, será importante instrumento de realização de escopos e valores, diante do Estado Democrático de Direito e do objetivo central, da República Federativa do Brasil, de construir uma sociedade livre, justa e solidária (arts. $1^{\circ}$, caput, e $3^{\circ}$, I, da Constituição).

\subsection{Tutela labor-ambiental}

O conceito de meio ambiente, nele incluído o do trabalho, revela-se onipresente, e afeta as relações laborais das mais diversas formas:

[...] o meio ambiente do trabalho é um dos principais focos de nascimento e irradiação de poluição [...] Segundo António Barreto Archer, é princípio fundamental do Direito 
Ambiental o "princípio da correção na fonte, que aconselha a combater a poluição o mais próximo possível da sua fonte, quer em sentido subjetivo, procurando o primeiro sujeito poluidor, quer em sentido espacial, procurando o foco inicial, quer em sentido temporal, procurando atuar logo no início do fenômeno de poluição" (MARANHÃO, 2017b, p. 23).

O não pagamento dos salários de forma pontual e correta ao empregado, por exemplo, causa-lhe grandes transtornos na sua vida, de toda ordem (desde restrições no mercado até a carência para aquisição de bens materiais básicos de sobrevivência, como alimentação); essas perturbações ocorrem, igualmente, com jornadas de trabalho exageradamente extensivas, com o não pagamento do labor correspondente a elas; com a simples não entrega da CTPS ao empregado dispensado, que fatalmente não terá contratação formal superveniente, em razão disso etc. $O$ descumprimento das obrigações contratuais, de toda ordem, leva o empregado, por exemplo, a diversas afetações em sua biopsicossocialidade.

A par desses descumprimentos contratuais específicos - de cláusulas contratuais -, a relação de emprego, tomada como "instrumento a serviço da pessoa e de sua dignidade", deve "refletir a primazia dos interesses existenciais sobre os interesses patrimoniais" (NEGREIROS, 2006, p. 461). Essa visão é adequada à tutela da dignidade da pessoa humana, a partir de ditames de justiça social, considerando-se, especialmente, que a ordem econômica é fundada na valorização do trabalho humano e na livre iniciativa (impregnada igualmente de valores sociais, segundo art. $1^{\circ}, \mathrm{IV}$, da Constituição) e tem por fim assegurar a todos uma existência digna (nesse sentido, é o art. 170, caput, da Constituição).

Por essa razão, muito mais do que "pagar o salário", o empregador tem para si o poder/dever ${ }^{13}$ de tutelar e fazer tutelar (arts. 932, III, e 933 do Código Civil), adequadamente, o meio ambiente do trabalho, não fragilizando a existência do empregado, respeitando seus projetos de vida, tratando-o com educação e respeito, não praticando nem permitindo a prática de qualquer tipo de assédio, mantendo o meio ambiente do trabalho $100 \%$ seguro ou minimamente inseguro - corolário dos princípios do risco mínimo regressivo ${ }^{14} \mathrm{e}$ da retenção do risco na fonte ${ }^{15}$ - etc.

13 Diz-se "poder/dever" inspirado, no poder, pelo poder empregatício em favor do empregador, nas relações de emprego (poder diretivo, regulamentar, fiscalizatório e disciplinar), e dever diante de todo $\mathrm{o}$ arcabouço constitucional de proteção à dignidade da pessoa humana.

14 "O empregador tem o dever de reduzir os riscos inerentes ao trabalho até onde for possível, em cada época, de modo que os danos sofridos pelo trabalhador por riscos que poderiam ter sido eliminados ou controlados ensejam a caracterização da conduta culposa, pela não observância do princípio do risco mínimo regressivo" (OLIVEIRA, 2017, p. 95).

15 "[...] estabelece como obrigação do empregador a identificação dos riscos previsíveis em todas 
O objeto do contrato de trabalho é para o empregado recurso de sobrevivência e vivência digna.

O Direito do Trabalho é protetivo, mediante a hipossuficiência do empregado, o qual precisa do salário para sobreviver, em relação ao empregador, detentor do uso do poder empregatício, tendo a seu favor o pressuposto da subordinação jurídica do empregado.

Nesse sentido, temos o "paradigma da essencialidade": o direito contratual, tomado como "instrumento a serviço da pessoa e de sua dignidade", deve "refletir a primazia dos interesses existenciais sobre os interesses patrimoniais" (NEGREIROS, 2006, p. 461). Não se trata "de tutelar mais ou menos as situações patrimoniais, mas de se lhes reservar uma tutela qualitativamente diversa" (NEGREIROS, 2006, p. 462), que deve concretizar, adequadamente, os direitos da personalidade e a tutela da dignidade da pessoa humana.

É nestes quadros que se torna importante distinguir aquelas situações patrimoniais - especificamente as relações contratuais - qualificadas em função de sua utilidade existencial, como tal entendido o grau de imprescindibilidade da aquisição ou utilização pessoal do bem em questão para a conservação de um padrão mínimo de dignidade de quem dele necessita. A destinação do bem objeto do contrato é um elemento fundamental na determinação do relativo poder negocial dos contratantes, e por isso deve ser levada em conta na solução do conflito de interesses que eventualmente sobrevenha.

Estas são as premissas que fundamentam o estabelecimento do paradigma da essencialidade. Os contratos que versem sobre a aquisição ou a utilização de bens que, considerando a sua destinação, são tidos como essenciais estão sujeitos a um regime tutelar, justificado pela necessidade de proteção da parte vulnerável - assim entendida a parte contratante que necessita do bem em questão -; e, vice-versa, no extremo oposto, os contratos que tenham por objeto bens supérfluos regem-se predominantemente pelos princípios do direito contratual clássico, vigorando aqui a regra da mínima intervenção heterônoma (NEGREIROS, 2006, p. 463).

No contrato de trabalho, uma das partes (o empregado, hipossuficiente) tem no objeto do contrato (a prestação do labor) sua única possibilidade de existência digna (a percepção salarial), o que legitima a intervenção estatal na autonomia da vontade privada, dada a assimetria característica da relação contratual.

Além do trabalho propriamente dito, outros direitos sociais fundamentais expressos no art. $6^{\circ}$ dependem, precipuamente, do fruto do as atividades da empresa, estabelecimento ou serviço, na concepção ou construção de instalações, de locais e processos de trabalho, assim como na seleção de equipamentos, substâncias e produtos, com vista à eliminação dos mesmos ou, quando esta seja inviável, à redução dos seus efeitos. Prevê também o combate aos riscos na origem, por forma a eliminar ou reduzir a exposição e aumentar os níveis de proteção" (OLIVEIRA, 2017, p. 96). 
labor (salário): em que pese o dever de prestação positiva estatal, sabe-se que educação, saúde, alimentação, moradia, transporte, lazer e previdência social estão contidos no conteúdo jurídico-constitucional do salário, que deve ser capaz de atender às necessidades vitais básicas do indivíduo e da sua família com o dispêndio desses direitos sociais fundamentais (art. $7^{\circ}$, IV, da Constituição).

Segundo o art. $225, \S 3^{\circ}$, da Constituição, as condutas e atividades consideradas lesivas ao meio ambiente - nele compreendido o do trabalho - sujeitam os infratores, pessoas físicas ou jurídicas, a sanções penais e administrativas, independentemente da obrigação de reparar os danos causados. Nesse sentido, a Constituição "adotou amplo sistema de responsabilidade por danos ambientais" (PADILHA, 2011, p. 252).

O princípio da solidariedade, enquanto marco jurídico-constitucional do Estado Socioambiental de Direito, fundamenta a responsabilidade compartilhada em matéria ambiental, "tendo em vista que os direitos de terceira geração ou de solidariedade são caracterizados como individuais e coletivos cuja realização depende da cooperação e solidariedade dos indivíduos" (BRITO; ZUBERI; BRITO, 2018, p. 72).

$\mathrm{O}$ art. $225, \S 3^{\circ}$, da Constituição se correlaciona a outros, do mesmo texto: $5^{\circ}, \mathrm{V}$ e X (dano extrapatrimonial), $5^{\circ}$, XXII e XXIII (direito de propriedade) e 170, 184 e 186 (função social da propriedade) (LEITE, 2013, p. 2105).

Embora inexista uma definição constitucional ou legal para "dano ambiental", ele pode ser conceituado como "qualquer lesão intolerável causada por ação humana, culposa ou não, que incide diretamente sobre o meio ambiente como macrobem de interesse coletivo e, indiretamente, a terceiros, em razão de seus interesses próprios e individualizáveis" (LEITE, 2013, p. 2107, sem o grifo no original).

A definição legal de meio ambiente se encontra na Lei n. 6.938/1981, segundo a qual "meio ambiente" é "o conjunto de condições, leis, influências e interações de ordem física, química e biológica, que permite, abriga e rege a vida em todas as suas formas" (art. $3^{\circ}, \mathrm{I}$ ).

Essa definição possui "significado abrangente e integrado" e foi "recepcionada e ampliada pelo texto constitucional", de modo que meio ambiente "pode ser considerado um macrobem de uso comum do povo, incorpóreo e imaterial, uma vez que não se confunde com a soma das partes"; "engloba não apenas bens naturais, mas também todos aqueles artificiais que fazem parte da vida humana, como patrimônio artístico, histórico e cultural" (LEITE, 2013, p. 2107), aí compreendido o meio ambiente do trabalho. 
Ainda em relação à Lei n. 6.938/1981, o art. $1^{\circ}$ compõe a "parte preliminar" da Lei (art. $3^{\circ}$, I, da Lei Complementar n. 95/1998) e diz que ela tem fundamento nos arts. 23, VI e VII, e 225 da Constituição de 1988, o que é um detalhe importantíssimo: o art. 23 trata da competência comum da União, dos Estados, do Distrito Federal e dos Municípios, dentre as quais a de proteger o meio ambiente e combater a poluição em qualquer de suas formas.

Se o art. 23, VI, da Constituição trata de tamanha amplitude, se a Lei n. 6.938/1981 é corolário dessa amplitude e se o conceito de meio ambiente inclui o meio ambiente do trabalho, é de concluir que o conceito de poluição tem repercussões na seara laboral.

Nesse sentido, conceitua-se poluição labor-ambiental nos seguintes termos:

[...] é o desequilíbrio sistêmico no arranjo das condições de trabalho, da organização do trabalho ou das relações interpessoais havidas no âmbito do meio ambiente laboral que, tendo base antrópica, gera riscos intoleráveis à segurança e à saúde física e mental do ser humano exposto a qualquer contexto jurídico-laborativo - arrostando-lhe, assim, a sadia qualidade de vida (CF, art. 225, caput) (MARANHÃO, 2017a, p. 234).

Tal conceitual, adequado à tutela labor-ambiental, atinge a inteireza dos fatores de risco sentidos no meio ambiente do trabalho:

\begin{abstract}
No nosso modo de ver, o acatamento dessa referência conceitual implica considerável alargamento do raio de incidência da noção jurídica de degradação ambiental, fazendo com que os rigores da axiologia jusambiental sejam inteiramente canalizados para o interior do meio ambiente do trabalho, influenciando-o por completo, de sorte a atingir a inteireza dos fatores de risco labor-ambientais (MARANHÃO, 2017a, p. 234).
\end{abstract}

Assim, dentro da gestão de riscos labor-ambientais, têm-se as condições de trabalho, entendidas as "condições físico-estruturais havidas no ambiente de trabalho", a organização do trabalho, considerado o "arranjo técnico-organizacional estabelecido para a execução do trabalho", e as relações interpessoais, entendidas as "interações socioprofissionais travadas no cotidiano do trabalho" (MARANHÃO, 2017a, p. 234), todas demandando qualidade: qualidade de vida, em sua forma plena, abrangendo todos os aspectos da vida humana, e qualidade de vida no (e dentro do) trabalho.

A própria Lei n. 6.938/1981, em recurso hermenêutico quase literal-gramatical, bem explicita essa noção labor-ambiental e firma a premissa 
de que "poluição" (art. $3^{\circ}$, III, "b") é a degradação da qualidade ambiental resultante de atividades que direta ou indiretamente, criem condições adversas às atividades sociais e econômicas.

Como se vê, a ideia de meio ambiente do trabalho não está implícita na Lei, ao contrário, ela própria inclui, em seu conceitual, a ideia de degradação labor-ambiental. Sequer caberia perquirir a extensão de "atividade social" ou de "atividade econômica", para fins da Lei n. 6.938/1981, pois, conforme dicção da própria Lei, essas condições adversas decorrem não apenas da degradação ambiental direta, mas, igualmente, de degradação indireta (art. $3^{\circ}$, III, caput), o que demonstra o espírito da norma em pretender alargar, o máximo possível, o campo de sua abrangência e aplicação.

De outra banda, o art. $3^{\circ}$, IV, da Lei n. 6.938/1981 afirma que "poluidor" é a "pessoa física ou jurídica, de direito público ou privado, responsável, direta ou indiretamente, por atividade causadora de degradação ambiental".

A considerar que a ideia de degradação ambiental abarca o meio ambiente do trabalho, é sugestivo concluir que o empregador, enquanto figura juridicamente elevada dentro das relações trabalhistas e detentor do poder empregatício, é pessoa natural ou jurídica capaz de causar degradação labor-ambiental e, por conseguinte, pode ser obrigado a reparar o dano que, por ato ilícito, causar ao empregado, independentemente de culpa.

Aqui, não há aplicação da regra, prevista no art. $7^{\circ}$, XXVIII, da Constituição, pois há uma especificidade que atrai a incidência da Lei n. 6.938/1981, que, nesse caso, é lei especial, aplicável especificamente à tutela labor-ambiental e adequada ao princípio constitucional de vedação ao retrocesso social e à cláusula de avanço social.

Assim, à tutela labor-ambiental, em caso de poluição labor-ambiental, o empregador-poluidor se sujeita à regra do art. $14, \S 1^{\circ}$, da Lei n. $6.938 / 1981$, que diz o seguinte:

\footnotetext{
Sem obstar a aplicação das penalidades previstas neste artigo, é o poluidor obrigado, independentemente da existência de culpa, a indenizar ou reparar os danos causados ao meio ambiente e a terceiros, afetados por sua atividade. O Ministério Público da União e dos Estados terá legitimidade para propor ação de responsabilidade civil e criminal, por danos causados ao meio ambiente. ${ }^{16}$
}

\footnotetext{
$16 \mathrm{O}$ art. $14, \S 1^{\circ}$, da Lei n. 6.938/1981 reconhece tanto a tutela individual, por meio de reclamações trabalhistas individuais ou plúrimas, como por meio do MPT, que terá legitimidade para propor ação de responsabilidade pelos danos causados ao meio ambiente do trabalho, órgão constitucionalmente (art. 127 da Constituição) adequado para promover a ação civil pública no âmbito da Justiça do Trabalho, para defesa de interesses coletivos, quando desrespeitados os direitos sociais constitucionalmente garantidos (art. 83, III, da Lei Complementar n. 75/1993), inclusive nas causas instauradas contra o Poder Público nas relações jurídico-estatutárias, segundo entendimento consolidado na Súmula n. 736 do STF.
} 
Trata-se de corolário da aplicação do princípio do poluidor-pagador ${ }^{17}$, definido pelo STJ como o princípio de que impõe a "internalização das externalidades ambientais negativas", no sentido de "substituir, mitigar, postergar ou dificultar o dever, a cargo do degradador material ou principal, de recuperação integral do meio ambiente afetado e de indenização pelos prejuízos causados"18.

Ora, é princípio informador do Direito Ambiental que os custos sociais externos que acompanham a produção industrial (como o custo resultante da poluição), devem ser internalizados, isto é, levados à conta dos agentes econômicos em seus custos de produção. [...] eis o princípio do poluidor-pagador, devidamente enunciado. Pois bem: parece evidente que, se há poluição, também nos locais de trabalho (inclusive na acepção da Lei n. 6.938/81), então os custos oriundos dos danos por ela provocados - ao entorno ambiental (=efeitos exógenos) ou a terceiros direta ou indiretamente expostos, como os trabalhadores (=efeitos endógenos) - devem ser igualmente internalizados, independentemente da perquirição de culpa (art. 14, § $1^{\circ}$, da Lei n. 6.938/81), para que os suporte o próprio agente poluidor (FELICIANO, 2013, p. 19 apud GONDIM, 2018, p. 185).

\section{A reparação deve ser ampla, segundo o $\mathrm{STJ}^{19}$ :}

Qualquer que seja a qualificação jurídica do degradador, público ou privado, no Direito brasileiro a responsabilidade civil pelo dano ambiental é de natureza objetiva, solidária e ilimitada, sendo regida pelos princípios do poluidor-pagador, da reparação in integrum ${ }^{20}$, da prioridade da reparação in natura ${ }^{21}$, e do favor debilis ${ }^{22}$, este último

17 Consideram-se, quanto a esse tema: (i) o Princípio n. 16 da Declaração do Rio sobre o Meio Ambiente e o Desenvolvimento (ECO-1992), segundo o qual "as autoridades nacionais deveriam fomentar a internalização dos custos ambientais pelo poluidor ou degradador, e o uso de instrumentos econômicos que impliquem que o poluidor deve, em princípio, arcar com os custos da degradação ambiental"; (ii) o art. $225, \S 2^{\circ}$, da Constituição, pelo qual "aquele que explorar recursos minerais fica obrigado a recuperar o meio ambiente degradado, de acordo com solução técnica exigida pelo órgão público competente, na forma da lei", e o art. $4^{\circ}$, VII, da própria Lei n. 6.938/1981, segundo o qual "a Política Nacional do Meio Ambiente visará: [...] à imposição, ao poluidor e ao predador, da obrigação de recuperar e/ou indenizar os danos causados e, ao usuário, da contribuição pela utilização de recursos ambientais com fins econômicos.

18 STJ, Recurso Especial n. 1.071.741/SP, Relator: Ministro Herman Benjamin, Órgão Julgador: Segunda Turma, Data do Julgamento: 24/03/2009, Data da Publicação/Fonte: DJe 16/12/2010.

19 STJ, Recurso Especial n. 1.071.741/SP, idem.

20 "No Direito brasileiro, vigora o princípio da reparação in integrum ao dano ambiental, que é multifacetário (ética, temporal e ecologicamente falando, mas também quanto ao vasto universo das vítimas, que vão do indivíduo isolado à coletividade, às gerações futuras e aos próprios processos ecológicos em mesmos considerados)" (MEDEIROS NETO, 2014, p. 290).

21 "Pode-se, então, vislumbrar a hipótese viável de reparação in natura, levando-se satisfação à vítima sem que se recorra ao meio pecuniário de caráter compensatório, ainda que seja possível fazê-lo, complementarmente, se a forma natural não for suficiente para cumprir o objetivo de proporcionar uma integral reparação do dano" (MEDEIROS NETO, 2014, p. 93).

22 "A técnica do rateamento é amiúde excepcionado, seja no próprio Código Civil, seja em microssistemas especiais (o ambiental, p. ex.), mormente em decorrência do grau e tipo de risco de certas atividades ou da necessidade, lastreada no princípio do favor debilis, de assegurar maior proteção a 
a legitimar uma série de técnicas de facilitação do acesso à Justiça, entre as quais se inclui a inversão do ônus da prova em favor da vítima ambiental. Precedentes do STJ.

Há questões que, intuitivamente, não se inserem nessa dinâmica, como o mero atraso na anotação da CTPS quando o vínculo de emprego ainda se encontra em vigor. Porém, essa mesma questão pode ser considerada uma poluição labor-ambiental, quando se demonstrar que o empregado, no caso de retenção indevida da CTPS e a prova de que, em razão disso, o empregado se viu impossibilitado de conquistar outra ocupação no mercado de trabalho (registre-se, ainda, que a CLT não exige exclusividade no vínculo de emprego, podendo o empregado possuir mais de um emprego com carteira assinada, salvo cláusula contrária e expressa, na forma do art. 29 da CLT).

Outrossim, há questões que, por si só, são demandas laborais-ambientais. Os acidentes do trabalho e as doenças ocupacionais, por exemplo, "são emoldurados como poluição ao meio ambiente do trabalho, sendo importante a interpretação na proteção dos direitos fundamentais do trabalho" (SOARES, 2017, p. 75).

Régua segura para a aferição do que está jungido às questões labor-ambientais reside no (re)conhecimento da tutela dos direitos da personalidade. Tais direitos, plasmados no art. $5^{\circ}, \mathrm{V}$ e X, da Constituição (rol meramente exemplificativo), consubstanciam "verdadeira cláusula geral de proteção à personalidade", qual seja, o art. $1^{\circ}$, III, da Constituição, "que assegura a dignidade da pessoa humana como fundamento de todo Estado Democrático de Direito. Assim, toda a ordem jurídica deve ser interpretada à luz do princípio da máxima efetividade dos direitos de personalidade" (DALLEGRAVE NETO, 2017, p. 161).

No contrato de trabalho, o empregado se encontra em manifesto estado de vulnerabilidade, tanto na esfera do ser quanto na esfera do ter. A higidez e a segurança de seus bens e interesses existenciais, que se encontram submetidos à gestão do empregador, devem ser amplamente tuteladas, para que o trabalho seja digno. O Código Civil (arts. 11 a 21) prescreve, nesse sentido, "por meio de cláusulas abertas à construção hermenêutica, o caráter intransmissível, irrenunciável e indisponível de todos os direitos inerentes à personalidade" (CARVALHO, 2018, p. 327).

Porém, considerandoquejáexisteummicrossistemaderesponsabilidade civil objetiva que trata especificamente dos danos de natureza ambiental,

sujeitos ou bens tidos como particularmente vulneráveis. [...] o favor debilis [...] inspira a legislação ambiental e a solidariedade [...]" - STJ, Recurso Especial n. 1.071.741/SP, idem. 
justamente em razão dos arts. $225, \S 3^{\circ}$, da Constituição e $14, \S 1^{\circ}$, da Lei n. 6.938/1981, e considerando que o meio ambiente compreende o do trabalho (art. 200, VIII, da Constituição), por que se propõe, então, um novo microssistema, autônomo e independente?

A proposta procura pavimentar o caminho da autonomia científica do Direito Ambiental do Trabalho. A intenção é debater, dentro do espaço jurídico, igualmente no plano ético, com uma visão humanista adequada ao espírito libertador da Constituição. Não se intenciona, porém, debater uma ética meramente abstrata, desprezando qualquer força jurídica, até porque a tutela labor-ambiental é um poder/dever já positivado.

$\mathrm{O}$ próprio estudo do meio ambiente do trabalho, a par do meio ambiente em seu sentido lato, insere-se no contexto do Direito Ambiental do Trabalho, "ramo do Direito que se caracteriza como uma reorientação da tutela ambiental, propondo a discussão e reflexão a respeito da proteção jurídica do trabalhador no seu ambiente laboral diante de uma perspectiva de dignidade da pessoa humana" (NEVES; NEVES; SILVA, 2015, p. 13).

Essa reconhecida autonomia deve ser preservada e, por certo, expandida, enquanto "instrumento a serviço da pessoa e de sua dignidade" que deve "refletir a primazia dos interesses existenciais sobre os interesses patrimoniais" (NEGREIROS, 2006, p. 461).

\subsubsection{Responsabilidade civil-ambiental objetiva e o dano ao meio ambiente do trabalho}

Como registra Tupinambá (2018, p. 34), "na tentativa de se determinar o que seriam atividades arriscadas, o desenvolvimento da teoria do risco importou subclassificação de matizes complexas que deságuam em teorias como as do risco proveito, risco criado, risco de empresa e do risco integral".

A teoria do risco é "baseada na ideia de que quem tira proveito ou vantagem de uma atividade e causa dano a outrem tem o dever de repará-lo", sendo que a teoria do risco integral, "mais extremada, não admite qualquer excludente de nexo de causalidade" (TUPINAMBÁ, 2018, p. 34-35).

Para Molina (2013, p. 78), "no limite, quando o microssistema recolher a teoria do risco integral, não socorrerá ao ofensor comprovar nenhuma das quatro excludentes de nexo, quando haverá dever de indenizar pela mera existência de dano". 
Pois bem.

Segundo o STJ ${ }^{23}$,

[...] a responsabilidade por dano ambiental é objetiva, informada pela teoria do risco integral, sendo o nexo de causalidade o fator aglutinante que permite que o risco se integre na unidade do ato, sendo descabida a invocação, pela empresa responsável pelo dano ambiental, de excludentes de responsabilidade civil para afastar sua obrigação de indenizar.

Ainda segundo o STJ, "a responsabilidade civil por danos ambientais, seja por lesão ao meio ambiente propriamente dito (dano ambiental público), seja por ofensa a direitos individuais (dano ambiental privado), é objetiva, fundada na teoria do risco integral"24.

Conforme destacou Machado (2017, p. 356), a jurisprudência do STJ demonstra, "com clareza, que a aplicação da teoria do risco integral na responsabilidade objetiva ambiental exige a comprovação do nexo causal entre a autoria e o dano ambiental".

Como se vê, a responsabilidade é objetiva, fundada na teoria do risco integral, apenas se exigindo que exista o dano ambiental e o nexo de causalidade a ligar autor e vítima ao evento danoso, sendo descabida, no dizer do próprio STJ, a invocação de qualquer excludente de responsabilidade civil (fato da vítima, fato de terceiro, caso fortuito interno ou externo e força maior).

Porém, embora compita ao STJ a uniformização da interpretação da legislação infraconstitucional em âmbito nacional, na forma do art. 105, III, da Constituição, a Corte Superior é incompetente para processar e julgar as ações oriundas das relações de trabalho regidas pela CLT, cuja incumbência, por delegação constitucional, é da Justiça do Trabalho, na forma do art. 114, I, da Constituição.

Veja-se que interessante. O STJ, mesmo com competência para uniformizar a interpretação da legislação infraconstitucional, sem poder recorrer à análise de afronta direta e literal à Constituição, que fica reservada ao STJ, tem interpretação, quanto aos danos ambientais, mais consentânea com a promessa constitucional de construção de uma sociedade mais justa, fraterna e solidária.

O TST é o órgão de cúpula da Justiça do Trabalho (art. 111, I, da

23 STJ, REsp n. 1.374.284/MG, Relator: Ministro Luis Felipe Salomão, Segunda Seção, julgado em 27/8/2014, DJe de 5/9/2014; STJ, REsp n. 1.354.536/SE, Relator: Ministro Luis Felipe Salomão, Segunda Seção, julgado em 26/3/2014, DJe de 5/5/2014.

24 STJ, REsp n. 1.373.788/SP, Relator: Ministro Paulo de Tarso Sanseverino, Terceira Turma, julgado em 6/5/2014, DJe de 20/5/2014. 
Constituição) e tem competência para uniformizar a interpretação trabalhista constitucional e infraconstitucional. Isso porque, segundo o art. 111-A, $\S 1^{\circ}$, da Constituição, combinado com os arts. 894 e 896 da CLT, reserva ao TST a competência para analisar decisões, na Justiça do Trabalho, "proferidas com violação literal de disposição de lei federal ou afronta direta e literal à Constituição Federal".

E a mais alta Corte da Justiça do Trabalho, embora julgue somente matéria dita especializada porque deve ser mais sensível às desigualdades que advêm das relações de trabalho, interpreta a jurisprudência trabalhista nacional, quanto aos danos ao meio ambiente do trabalho, de forma restrita e, no geral, resume-se à aplicação do art. $7^{\circ}$, XXVIII, da Constituição, que imputa ao empregador a obrigação de indenizar "quando incorrer em dolo ou culpa".

Mesmo nos casos de responsabilidade civil objetiva, nas relações de trabalho, calcada no art. 927, parágrafo único, do Código Civil, por força do art. 769 da CLT, a jurisprudência do TST é restritiva, pois, ao admitir as excludentes de responsabilidade, afasta a responsabilidade civil do empregador em casos de violência urbana, por exemplo, quando se sabe, como visto, ser obrigação do empregador a manutenção de um meio ambiente do trabalho $100 \%$ seguro ou minimamente inseguro - corolário dos princípios do risco mínimo regressivo e da retenção do risco na fonte.

Veja-se, exemplificadamente:

Agravo. Acidente. Responsabilidade civil objetiva. Culpa exclusiva da vítima. Rompimento do nexo de causalidade. Para a caracterização do dever de indenizar, mesmo em se tratando de responsabilidade objetiva, devem estar presentes o dano e o nexo de causalidade entre as funções desempenhadas e o acidente. A existência de culpa exclusiva da vítima rompe o próprio nexo causal, uma vez que não se pode ter por decorrente das funções desempenhadas pelo autor um acidente que ele causou por imprudência própria. Em casos tais, não há dever de reparar, uma vez que inaplicável à seara trabalhista a teoria do risco integral, salvo nos casos constitucionalmente previstos (art. 21, XXIII, “d” e 225, § 30, da Constituição Federal - danos nucleares e ambientais). Agravo a que se nega provimento. (TSTAg-AIRR-55900-87.2006.5.03.0053, Relator Ministro: Guilherme Augusto Caputo Bastos, Data de Julgamento: 11/12/2013, $5^{\text {a }}$ Turma, Data de Publicação: DEJT $19 / 12 / 2013)$

Em julgamento no TRT de São Paulo, processo n. 1000701-08.2015.5.02.0431, discutia-se a responsabilidade civil do empregador por empregado que, no exercício da função de carteiro motorizado, sofreu cinco assaltos no exercício de suas atividades laborais. 
Segundo o TRT, o empregador não poderia ser responsabilizado, pois mesmo que

[...] providenciasse escolta armada para todos os carteiros, o que parece inviável, ainda assim não há garantias de que não ocorressem os assaltos, pois é notório que a violência urbana no Brasil chegou a limites intoleráveis e, infelizmente, todos os cidadãos estão expostos a essa violência crescente.

Assim, o TRT de São Paulo concluiu tratar-se de fato de terceiro, que "exclui a responsabilidade da empregadora, que é, repita-se, subjetiva, não havendo se falar no dever de reparar a lesão".

Doutrinariamente, diz-se que, "conceitualmente, há no direito atual duas hipóteses de responsabilidade por risco integral, entretanto, nenhuma delas incidentes nas relações de trabalho" e que "não há microssistema algum que preveja responsabilidade por risco integral" (MOLINA, 2013, p. 79; 112).

Como se viu anteriormente, há uma série de danos possíveis ao meio ambiente do trabalho, sendo expressivas demandas laborais-ambientais, como os acidentes do trabalho e as doenças ocupacionais, "emoldurados como poluição ao meio ambiente do trabalho, sendo importante a interpretação na proteção dos direitos fundamentais do trabalho" (SOARES, 2017, p. 75).

Nesse diapasão, o olhar crítico sobre a doutrina e a jurisprudência e, portanto, sobre a hermenêutica atual acentua ainda mais a importância de um microssistema de responsabilidade civil objetiva, autônomo e independente, que trate especificamente dos danos de natureza ambiental, na forma dos arts. $225, \S 3^{\circ}$, da Constituição e $14, \S 1^{\circ}$, da Lei n. 6.938/1981.

De modo prático, no caso do carteiro, por exemplo, explanado acima, a insuficiência da teoria da culpabilidade, conduz-nos à aplicação da teoria do risco integral, pois o empregador deve arcar com os riscos do negócio e pelos riscos e perigos que sua atividade promova ainda que empregue toda diligência para evitar o dano ${ }^{25}$, como nos sugere a própria CLT (art. $2^{\circ}$, caput): "Considera-se empregador a empresa, individual ou coletiva, que, assumindo os riscos da atividade econômica, admite, assalaria e dirige a prestação pessoal de serviço".

Conforme ensina Ney Maranhão, em uma abordagem fenomênica dos elementos que compõem o meio ambiente do trabalho, o ambiente está

25 No julgamento do RR-1000701-08.2015.5.02.0431, $5^{\text {a }}$ Turma, Relator: Ministro Douglas Alencar Rodrigues, DEJT 25/10/2018, o TST reconheceu a aplicabilidade da responsabilidade civil objetiva, mas não adotou a teoria do risco integral, mas do risco criado, e não reconheceu a situação como dano ao meio ambiente do trabalho. 
no entorno do ser humano, no espaço físico; já o meio ambiente carrega uma ideia complexa, interativa de que o ser humano está incluído. No caso concreto citado, do carteiro, se sua atividade é externa, por certo as vicissitudes da rua compõem o meio ambiente do trabalho.

Assentir com a irresponsabilidade civil do empregador, nesse caso, é assentir com a assunção dos riscos do negócio pelo empregado.

\section{CONCLUSÃO}

Dada a inafastabilidade da jurisdição e a exclusividade do Poder Judiciário em dizer o direito e dar a última palavra em toda e qualquer nuança da vida humana e do mundo fenomênico, a interpretação judicial pode (deve) ser considerada a régua da cidadania.

Nesse sentido, o juiz, ao aplicar o ordenamento jurídico, deve atender aos fins sociais e às exigências do bem comum, resguardando e promovendo a dignidade da pessoa humana, segundo art. $8^{\circ}$ do CPC, o que demanda "a exigência de um comportamento mais ativo do magistrado" (DIDIER JÚNIOR, 2016, p. 76-77).

O Direito Ambiental do Trabalho, enquanto ramo destacado do Direito, ao reorientar a tutela ambiental "diante de uma perspectiva de dignidade da pessoa humana” (NEVES; NEVES; SILVA, 2015, p. 13), é dotado de plena autonomia científica, segundo se observa do próprio mundo fenomênico e, ainda, do estudo deôntico da normatividade jurídica, o que deve ser prestigiado.

Considerada a saúde como um elemento biopsicossocial, na forma da Constituição da Organização Mundial de Saúde e da Convenção n. 155 da OIT, o meio ambiente do trabalho deve ser visto a partir de uma visão multidimensional, capaz de compreender todas as suas causalidades. E sendo um direito social implícito no art. $6^{\circ}$ da Constituição da República, deve ter enfoque humanista, holístico, democrático e participativo.

A concepção do meio ambiente, tida em sua totalidade, considera a interdependência entre o meio natural, o socioeconômico e o cultural, e vincula ética, educação, trabalho e práticas sociais.

A par da interação entre elementos naturais, artificiais e culturais, o meio ambiente compreende o do trabalho, representativo das relações laborais; a Lei n. 6.938/1981 explicita essa noção labor-ambiental e firma a premissa de que "poluição" (art. $3^{\circ}$, III, "b") é a degradação da qualidade ambiental resultante de atividades que direta ou indiretamente, criem 
condições adversas às atividades sociais e econômicas.

Em que pesem tais premissas, a Justiça do Trabalho tem desenvolvido um sistema interpretativo aquém da adequada proteção que se espera ao meio ambiente do trabalho e à tutela labor-ambiental, capitulando os danos ambientais trabalhistas dentro da regra trabalhista inserta no art. $7^{\circ}$, XXVIII, da Constituição, que consagra a responsabilidade civil subjetiva e exige, além do efetivo dano e do nexo causal que liga autor e vítima ao evento danoso, a ocorrência de dolo ou culpa.

Constatado o quadro de capitis diminutio interpretativo, e a partir da autoridade moral da Constituição da República e do sistema jusconstitucional brasileiro que congrega inúmeros tratados internacionais de direitos humanos, como o Pacto Internacional sobre Direitos Econômicos, Sociais e Culturais, propôs-se um novo microssistema de responsabilidade civil objetiva, a par dos microssistemas já reconhecidos, autônomo e independente, de responsabilidade do empregador-poluidor, em caso de poluição labor-ambiental, a partir dos arts. 200, VIII, e 225, $\S$ $3^{\circ}$, da Constituição e do art. 14 , $\S 1^{\circ}$, da Lei n. 6.938/1981.

Para o sistema proposto, se o dano se insere na dinâmica do meio ambiente do trabalho, a responsabilidade é objetiva, informada pela teoria do risco integral, sendo o nexo de causalidade o fator aglutinante que permite que o risco se integre na unidade do ato, não se admitindo excludentes da responsabilidade civil para afastar sua obrigação de indenizar.

Espera-se, com isso, pavimentar o caminho da autonomia científica do Direito Ambiental do Trabalho, sempre com o olhar elevado à dignidade da pessoa humana e aos valores sociais do trabalho e da livre iniciativa.

\section{REFERÊNCIAS}

BALERA, W. A seguridade social na Constituição de 1988. São Paulo: Revista dos Tribunais, 1989.

BRASIL. Decreto-Lei n. 4.657, de 4 de setembro de 1942. Lei de Introdução às normas do Direito Brasileiro. Brasília, DF: Presidência da República, 1942. Disponível em: <http://www.planalto.gov.br/ccivil_03/decreto-lei/ Del4657.htm>. Acesso em: 30 jun. 2019.

BRASIL. Decreto-Lei $n$. 5.452, de $1^{\circ}$ de maio de 1943. Aprova a Consolidação das Leis do Trabalho. Brasília, DF: Presidência da República, 
1943. Disponível em: <https://www.planalto.gov.br/ccivil_03/decreto-lei/ Del5452.htm>. Acesso em: 30 jun. 2019.

BRASIL. Decreto-Lei $n$. 227, de 28 de fevereiro de 1967. Dá nova redação ao Decreto-lei n. 1.985, de 29 de janeiro de 1940. (Código de Minas). Brasília, DF: Presidência da República, 1967. Disponível em: $<$ http:// www.planalto.gov.br/ccivil_03/decreto-lei/del0227.htm>. Acesso em: 30 jun. 2019.

BRASIL. Lei $n$. 6.453, de 17 de outubro de 1977. Dispõe sobre a responsabilidade civil por danos nucleares e a responsabilidade criminal por atos relacionados com atividades nucleares e dá outras providências. Brasília, DF: Presidência da República, 1977. Disponível em: <http:// www.planalto.gov.br/ccivil_03/leis/L6453.htm>. Acesso em: 30 jun. 2019.

BRASIL. Lei $n$. 6.938, de 31 de agosto de 1981. Dispõe sobre a Política Nacional do Meio Ambiente, seus fins e mecanismos de formulação e aplicação, e dá outras providências. Brasília, DF: Presidência da República, 1981. Disponível em: <http://www.planalto.gov.br/ccivil_03/leis/16938. htm>. Acesso em: 30 jun. 2019.

BRASIL. Constituição da República Federativa do Brasil. Brasília, DF: Presidência da República, 1988. Disponível em: <https://www.planalto. gov.br/ccivil_03/constituicao/Constituicao.htm>. Acesso em: 30 jun. 2019.

BRASIL. Decreto n. 592, de 6 de julho de 1992. Atos Internacionais. Pacto Internacional sobre Direitos Civis e Políticos. Promulgação. Brasília, DF: Presidência da República, 1992. Disponível em: <http://www.planalto.gov. br/ccivil_03/decreto/1990-1994/d0592.htm>. Acesso em: 30 jun. 2019.

BRASIL. Lei Complementar n. 75, de 20 de maio de 1993. Dispõe sobre a organização, as atribuições e o estatuto do Ministério Público da União. Brasília, DF: Presidência da República, 1993. Disponível em: <http:// www.planalto.gov.br/ccivil_03/leis/lcp/lcp75.htm>. Acesso em: 30 jun. 2019.

BRASIL. Decreto $n$. 1.254, de 29 de setembro de 1994. Promulga a Convenção número 155, da Organização Internacional do Trabalho, sobre Segurança e Saúde dos Trabalhadores e o Meio Ambiente de Trabalho, concluída em Genebra, em 22 de junho de 1981. Brasília, DF: Presidência 
da República, 1994. Disponível em: <http://www.planalto.gov.br/ ccivil_03/decreto/1990-1994/D1254.htm>. Acesso em: 30 jun. 2019.

BRASIL. Lei Complementar n. 95, de 26 de fevereiro de 1998. Dispõe sobre a elaboração, a redação, a alteração e a consolidação das leis, conforme determina o parágrafo único do art. 59 da Constituição Federal, e estabelece normas para a consolidação dos atos normativos que menciona. Brasília, DF: Presidência da República, 1998. Disponível em: $<$ http:// www.planalto.gov.br/ccivil_03/leis/lcp/lcp95.htm>. Acesso em: 30 jun. 2019.

BRASIL. Lei n. 9.795, de 27 de abril de 1999. Dispõe sobre a educação ambiental, institui a Política Nacional de Educação Ambiental e dá outras providências. Brasília, DF: Presidência da República, 1999. Disponível em: <http://www.planalto.gov.br/ccivil_03/leis/19795.htm>. Acesso em: 30 jun. 2019.

BRASIL. Lei n. 10.406, de 10 de janeiro de 2002. Institui o Código Civil. Brasília, DF: Presidência da República, 2002. Disponível em: <https:// www.planalto.gov.br/ccivil_03/leis/2002/L10406.htm>. Acesso em: 30 jun. 2019.

BRASIL. Súmula n. 736. Compete à justiça do trabalho julgar as ações que tenham como causa de pedir o descumprimento de normas trabalhistas relativas à segurança, higiene e saúde dos trabalhadores. Brasília, DF: Supremo Tribunal Federal, 2003. Disponível em: $<$ http://www.stf.jus.br/ portal/jurisprudencia/menuSumarioSumulas.asp?sumula $=2243>$. Acesso em: 30 jun. 2019.

BRASIL. Proposta de emenda à Constituição n. 16, de 2012. Altera a redação do artigo $6^{\circ}$ da Constituição Federal para acrescenta 'o meio ambiente saudável' entre os direitos sociais. Brasília, DF: Senado Federal, 2012. Disponível em: <https://legis.senado.leg.br/sdleg-getter/ documento $\mathrm{dm}=4044014 \& \mathrm{ts}=1553254814924 \&$ disposition=inline $>$. Acesso em: 30 jun. 2019.

BRASIL. Superior Tribunal de Justiça. Informativo de Jurisprudência, Brasília, DF, n. 513, 6 mar. 2013. Disponível em: <https://scon. stj.jus.br/SCON/SearchBRS?b=INFJ\&tipo=informativo\&livre=@ $\mathrm{COD}=\% 270513 \% 27>$. Acesso em: 30 jun. 2019 . 
BRASIL. Lei n. 13.105, de 16 de março de 2015. Código de Processo Civil. Brasília, DF: Presidência da República, 2015. Disponível em: <https:// www.planalto.gov.br/ccivil_03/_Ato2015-2018/2015/Lei/L13105.htm>. Acesso em: 30 jun. 2019.

BRASIL. Lei n. 13.467, de 13 de julho de 2017. Lei n. 13.467, de 13 de julho de 2017. Altera a Consolidação das Leis do Trabalho (CLT), aprovada pelo Decreto-Lei n. 5.452, de $1^{\circ}$ de maio de 1943, e as Leis n. 6.019 , de 3 de janeiro de 1974, 8.036, de 11 de maio de 1990, e 8.212, de 24 de julho de 1991, a fim de adequar a legislação às novas relações de trabalho. Brasília, DF: Presidência da República, 2017. Disponível em: $<$ http://www.planalto.gov.br/ccivil_03/_ato2015-2018/2017/lei/L13467. htm>. Acesso em: 30 jun. 2019.

BIRNFELD, C. A. S. Do ambientalismo à emergência das normas de proteção ambiental no Brasil. In: VARELLA, M. D.; BORGES, R. C. B. (Orgs.). O novo em direito ambiental. Belo Horizonte: Del Rey, 1998. p. 71-97.

BONNA, A. P. A vedação do retrocesso social como limite à flexibilização das normas trabalhistas brasileiras. Revista do Tribunal Regional do Trabalho da $3^{a}$ Região, Belo Horizonte, v. 47, n. 77, p. 51-66, jan./jun. 2008.

BRITO, F. J. S.; ZUBERI, T.; BRITO, V. S. S. A constitucionalização do meio ambiente no Brasil, Espanha e África do Sul: avanços e desafios. Veredas do Direito, Belo Horizonte, v. 15, n. 32, p. 67-85, maio/ago. 2018.

CANARIS, C.-W. Pensamento sistemático e conceito de sistema na ciência do direito. 3. ed. Lisboa: Fundação Calouste Gulbenkian, 2002.

CARVAlHO, A. C. L. Direito do trabalho: curso e discurso. 2. ed. São Paulo: LTr, 2018.

CATALAN, M. A morte da culpa na responsabilidade contratual. Tese (Doutoramento) - Faculdade de Direito, Universidade de São Paulo, São Paulo, 2011.

CONFERÊNCIA DAS NAÇÕES UNIDAS SOBRE MEIO AMBIENTE E DESENVOLVIMENTO. Declaração do Rio sobre Meio Ambiente $e$ Desenvolvimento. Disponível em: $<$ http://www.meioambiente. 
pr.gov.br/arquivos/File/agenda21/Declaracao_Rio_Meio_Ambiente_ Desenvolvimento.pdf $>$. Acesso em: 30 jun. 2019.

CONFERÊNCIA INTERNACIONAL SOBRE PROMOÇÃO DA SAÚDE. Carta de Ottawa. Disponível em: <http://bvsms.saude.gov.br/ bvs/publicacoes/carta_ottawa.pdf $>$. Acesso em: 30 jun. 2019.

CUNHA, R. S. Manual de Direito Penal: parte geral (arts. $1^{\circ}$ a 120). 7. ed. rev., atual. e ampl. Salvador: JusPODIVM, 2019.

CUNHA, T. H. L. Aspecto repressivo da tutela labor-ambiental: um estudo sobre o dano moral coletivo. In: FELICIANO, G. G. et al. (Coords.). Direito ambiental do trabalho: apontamentos para uma teoria geral. v. 2. São Paulo: LTr, 2015. p. 225-259.

DALLEGRAVE NETO, J. A. Dano ao ambiente de trabalho individual e coletivo: evolução e notas sobre prescrição e competência. In: GUNTHER, L. E.; ALVARENGA, R. Z. (Coords.). Direitos humanos e meio ambiente do trabalho. São Paulo: LTr, 2016. p. 69-80.

DALLEGRAVE NETO, J.A. Responsabilidade civil no direito do trabalho. 6. ed. São Paulo: LTr, 2017.

DELGADO, M. G. Curso de direito do trabalho. 17. ed. rev., atual. e ampl. São Paulo: LTr, 2018.

DIDIER JÚNIOR, F. Curso de direito processual civil: introdução ao Direito Processual Civil, parte geral e processo de conhecimento. 18. ed. rev., ampl. e atual. Salvador: JusPODIVM, 2016.

FIORILlo, C. A. P. In: CANOTILHO, J. J. G. et al. Comentários à Constituição do Brasil. Saraiva/Almedina: São Paulo/Portugal, 2013.

FRANÇA. Declaração de direitos do homem e do cidadão. Disponível em: <http://www.direitoshumanos.usp.br/index.php/Documentosanteriores- $\% \mathrm{C} 3 \% \mathrm{~A} 0$-cria $\% \mathrm{C} 3 \% \mathrm{~A} 7 \% \mathrm{C} 3 \% \mathrm{~A} 30$-da-Sociedade-dasNa\%C3\%A7\%C3\%B5es-at\%C3\%A9-1919/declaracao-de-direitos-dohomem-e-do-cidadao-1789.html>. Acesso em: 30 jun. 2019.

GONDIM, A. R. C. A responsabilidade por danos labor-ambientais no setor automobilístico. In: FELICIANO, G. G.; EBERT, P. R. L. (Coords.). 
Direito ambiental do trabalho: apontamentos para uma teoria geral. v. 4. São Paulo: LTr, 2018. p. 177-188.

JELLINEK, G. A declaração dos direitos do homem e do cidadão: contribuição para a história do direito constitucional moderno. São Paulo: Atlas, 2015.

KRELL, A. J. Do meio ambiente. In: CANOTILHO, J. J. G. et al. Comentários à Constituição do Brasil. São Paulo/Coimbra: Saraiva/ Almedina, 2013. p. 2077-2086.

LARENZ, K. Metodologia da ciência do Direito. 3. ed. Lisboa: Fundação Calouste Gulbenkian, 1997.

LEAL, C. R. F.; ROCHA, S. H. Riscos ambientais laborais na sociedade global e sua proteção jurídica. Veredas do Direito, Belo Horizonte, v. 15, n. 33, p. 263-290, set./dez. 2018.

LEITÃO, A. S.; MEIRINHO, A. G. S. A cidadania como pressuposto de concessão do benefício assistencial de prestação continuada da LOAS. In: FURTADO, E. T.; DIAS NETO, P. M. V. (Orgs.). Teoria da cidadania e direitos fundamentais. São Paulo: LTr, 2016. p. 41-52.

LEITE, J. R. M. Responsabilidade civil por dano ambiental. In: CANOTILHO, J. J. G. et al. Comentários à Constituição do Brasil. São Paulo/Coimbra: Saraiva/Almedina, 2013. p. 2104-2110.

MACHADO, P. A. L. STJ e nexo causal na responsabilidade civil. Veredas do Direito, Belo Horizonte, v. 14, n. 30, p. 351-371, set./dez. 2017.

MARANHÃO, N. Poluição labor-ambiental: abordagem conceitual da degradação das condições de trabalho, da organização do trabalho e das relações interpessoais travadas no contexto laborativo. Rio de Janeiro: Lumen Juris, 2017a.

MARANHÃO, N. Questões social e ambiental: paralelismos e desencontros na perspectiva do meio ambiente do trabalho. Revista Magister de Direito Ambiental e Urbanístico, Porto Alegre, n. 72, p. 5-29, jun./jul. 2017 b.

MARANHÃO, N. Meio ambiente do trabalho: relevância sociojurídica de seu reconhecimento constitucional e internacional. In: ROCHA, C. J. et al. (Coords.). Direito internacional do trabalho: aplicabilidade e eficácia dos 
instrumentos internacionais de proteção ao trabalhador. São Paulo: LTr, 2018. p. 289-295.

MEDEIROS NETO, X. T. Dano moral coletivo. 4. ed. ampl., atual. e rev. São Paulo: LTr, 2014.

MOLINA, A. A. Sistemas de responsabilidade civil objetiva e os acidentes de trabalho. Revista do TST, Brasília, v. 79, n. 2, p. 70-117, abr./jun. 2013.

MORAIS, J. L. B.; SARAIVA, B. C. O Estado de Direito Socioambiental como condição de possibilidade destinada à tutela do futuro. Veredas do Direito, Belo Horizonte, v. 15, n. 32, p. 11-37, maio/ago. 2018.

NEGREIROS, T. Teoria do contrato: novos paradigmas. 2. ed. Rio de Janeiro: Renovar, 2006.

NEVES, I. C. S.; NEVES, I. C. S.; SILVA, R. M. S. Direito ambiental do trabalho: o meio ambiente do trabalho, uma aproximação interdisciplinar. In: FELICIANO, G. G. et al. (Coords.). Direito ambiental do trabalho: apontamentos para uma teoria geral. v. 2. São Paulo: LTr, 2015. p. 13-20.

OLIVEIRA, S. G. Proteção jurídica à saúde do trabalhador. 6. ed. rev. e atual. São Paulo: LTr, 2011.

OLIVEIRA, S. G. Fundamentos da tutela labor-ambiental. In: FELICIANO, G. G.; URIAS, J.; MARANHÃO, N. Direito ambiental do trabalho: apontamentos para uma teoria geral. v. 3. São Paulo: LTr, 2017. p. 91-102.

ORGANIZAÇÃO DAS NAÇÕES UNIDAS. Constituição da Organização Mundial de Saúde. Disponível em: <http://www.direitoshumanos. usp.br/index.php/OMS-Organiza $\% \mathrm{C} 3 \% \mathrm{~A} 7 \% \mathrm{C} 3 \% \mathrm{~A} 30-$ Mundial-da$\mathrm{Sa} \% \mathrm{C} 3 \% \mathrm{BAde} /$ constituicao-da-organizacao-mundial-da-saude-omswho. html>. Acesso em: 30 jun. 2019.

ORGANIZAÇÃO DAS NAÇÕES UNIDAS. Declaração Universal dos Direitos Humanos. Disponível em: <https://nacoesunidas.org/wp-content/ uploads/2018/10/DUDH.pdf $>$. Acesso em: 30 jun. 2019.

PADILHA, N. S. O equilíbrio do meio ambiente do trabalho: direito fundamental do trabalhador e de espaço interdisciplinar entre o direito do trabalho e o direito ambiental. Revista do TST, Brasília, v. 77, n. 4, p. 231-258 , out./dez. 2011. 
SANTOS, E. R. Responsabilidade objetiva e subjetiva do empregador em face do novo Código Civil. 3. ed. rev. e ampl. São Paulo: LTr, 2015.

SARLET, I. W. As normas definidoras dos direitos e garantias fundamentais têm aplicação imediata. In: CANOTILHO, J. J. G. Comentários à Constituição do Brasil. São Paulo/Coimbra: Saraiva/Almedina, 2013a. p. 513-515.

SARLET, I. W. Dos direitos sociais. In: CANOTILHO, J. J. G. et al. Comentários à Constituição do Brasil. São Paulo/Coimbra: Saraiva/ Almedina, 2013b. p. 533-548.

SILVA, J. A. Direito ambiental constitucional. 2. ed. São Paulo: Malheiros, 1998.

SOARES, S. C. A. Direitos fundamentais do trabalho. São Paulo: LTr, 2017.

STOCO, R. Tratado de responsabilidade civil. 6. ed. rev., atual. e ampl. São Paulo: Revista dos Tribunais, 2004.

STRECK, L. L.; MORAIS, J. L. B. Estado democrático de direito. In: CANOTILHO, J. J. G. et al. Comentários à Constituição do Brasil. São Paulo/Coimbra: Saraiva/Almedina, 2013. p. 113-116.

TUPINAMBÁ, C. Danos extrapatrimoniais decorrentes das relações de trabalho. São Paulo: LTr, 2018.

VINEY, G.; JORDAIN, P. Traité de droit civil: les effets de la responsabilité. 3. ed. Paris: LGDJ, 2010.

Artigo recebido em: 28/02/2019. Artigo aceito em: 01/07/2019.

\section{Como citar este artigo (ABNT):}

LEAL, P. S. T.; ZWICKER, I. O. A responsabilidade objetiva do empregador à luz da proteção constitucional conferida ao meio ambiente do trabalho. 
Veredas do Direito, Belo Horizonte, v. 16, n. 35, p. 149-189, maio/ago. 2019. Disponível em: <http://www.domhelder.edu.br/revista/index.php/ veredas/article/view/1499>. Acesso em: dia mês. ano. 